\title{
Silurian vertebrate remains from the Oslo Region, Norway, and their implications for regional biostratigraphy
}

\author{
Oskar Bremer ${ }^{1}$, Susan Turner ${ }^{2}$, Tiiu Märss ${ }^{3}$ \& Henning Blom \\ ${ }^{1}$ Uppsala University, Department of Organismal Biology, Norbyvägen 18A, 752 36, Uppsala, Sweden. \\ ${ }^{2}$ Honorary Research Fellow, Queensland Museum Geosciences, 122 Gerler Road, Hendra, Queensland 4011, Australia. \\ ${ }^{3}$ Department of Geology at Tallinn University of Technology, Ehitajate tee 5, 19086 Tallinn, Estonia.
}

E-mail corresponding author (Oskar Bremer): oskar.bremer@ebc.uu.se.

Several vertebrate assemblages are described from the Silurian of the Oslo Region, Norway, based on the review and revision of previous reports of microremains, as well as unpublished material from museum collections. Articulated thelodont specimens from the Rudstangen Fauna, Ringerike Group, are also described here for the first time, revealing a seemingly monogeneric loganelliid assemblage. The oldest assemblage (mid-Llandovery) only contains the thelodont Loganellia cf. aldridgei, while a single sample from upper Llandovery strata produced four Thelodus sp. scales. These scales share features with those from younger Thelodus taxa and give additional support to an early appearance of this genus. The mid-Wenlock faunas consist of thelodonts Loganellia grossi, Loganellia einari and Thelodus laevis. These are joined by the thelodont Paralogania martinssoni, anaspids Rhyncholepis parvula and cf. Pterygolepis nitida, as well as the osteostracans cf. Tyriaspis whitei and Osteostraci gen. et sp. indet. in late Wenlock and earliest Ludlow faunas. These complement the previously described anaspids and osteostracans of the Rudstangen Fauna based on articulated specimens. The faunas of a number of calcarenite samples collectively contain the thelodonts $L$. grossi, L. einari, $P$. martinssoni and T. laevis, and are most likely of early Ludlow age. When the vertebrate-producing samples are put in the proposed stratigraphical framework for the Oslo Region that has been refined in recent decades, the faunas fit well into the vertebrate biozonation established for the Silurian, contrary to previous claims. The earliest faunas in the area show similarities to the Llandovery of Britain, whereas thelodonts and anaspids, but not osteostracans, from late Wenlock and early Ludlow are more closely related to Baltic forms. Additional sampling of the area may assist in refining the biostratigraphy and provide insights into Silurian vertebrate distributions in Norway and related regions.

Keywords: vertebrate palaeontology, agnathan remains, biostratigraphy, correlation, Llandovery-Ludlow, Oslo Region.

Electronic Supplement 1: Supplementary Material

Received 15. January 2019 / Accepted 31. May 2019 / Published online 10. September 2019

\section{Introduction}

Well-preserved vertebrate fossils of the well-known Rudstangen Fauna from the upper Silurian Ringerike Group in the Ringerike area northwest of Oslo (Fig. 1A) were first described by Kiær $(1911,1924)$. The fossils come from approximately $10 \mathrm{~m}$ above the base of the Sundvollen Formation of the Ringerike Group in this area (Turner \& Turner, 1974; Davies et al., 2005a) and include a number of anaspids (Kiær, 1924), the osteostracans Ateleaspis robusta and Hirella gracilis (Kiær, 1911), as well as previously mentioned but as yet undescribed articulated thelodonts (Heintz, 1939). Additional articulated specimens of anaspids and osteostracans were later described from this locality (Heintz, 1939; Smith, 1956, 1957; Ritchie, 1964; Blom et al., 2002). Heintz (1939) proposed a Ludlow age for the Rudstangen Fauna based on comparison with faunas from Britain, Estonia and southern Sweden. The nearby Nes locality, c. $1 \mathrm{~km}$ north of Rudstangen (Fig. 1B), was discovered later and produced the new osteostracans Ateleaspis sp., Hirella denisoni and Tyriaspis whitei, but no thelodonts or anaspids (Heintz, 1967, 1969). The two localities are separated by a fault, and Nes was therefore

Bremer, O., Turner, S., Märss, T. \& Blom, H. 2019: Silurian vertebrate remains from the Oslo Region, Norway, and their implications for regional biostratigraphy. Norwegian Journal of Geology 99, 129-155. https://dx.doi.org/10.17850/njg99-1-07. 


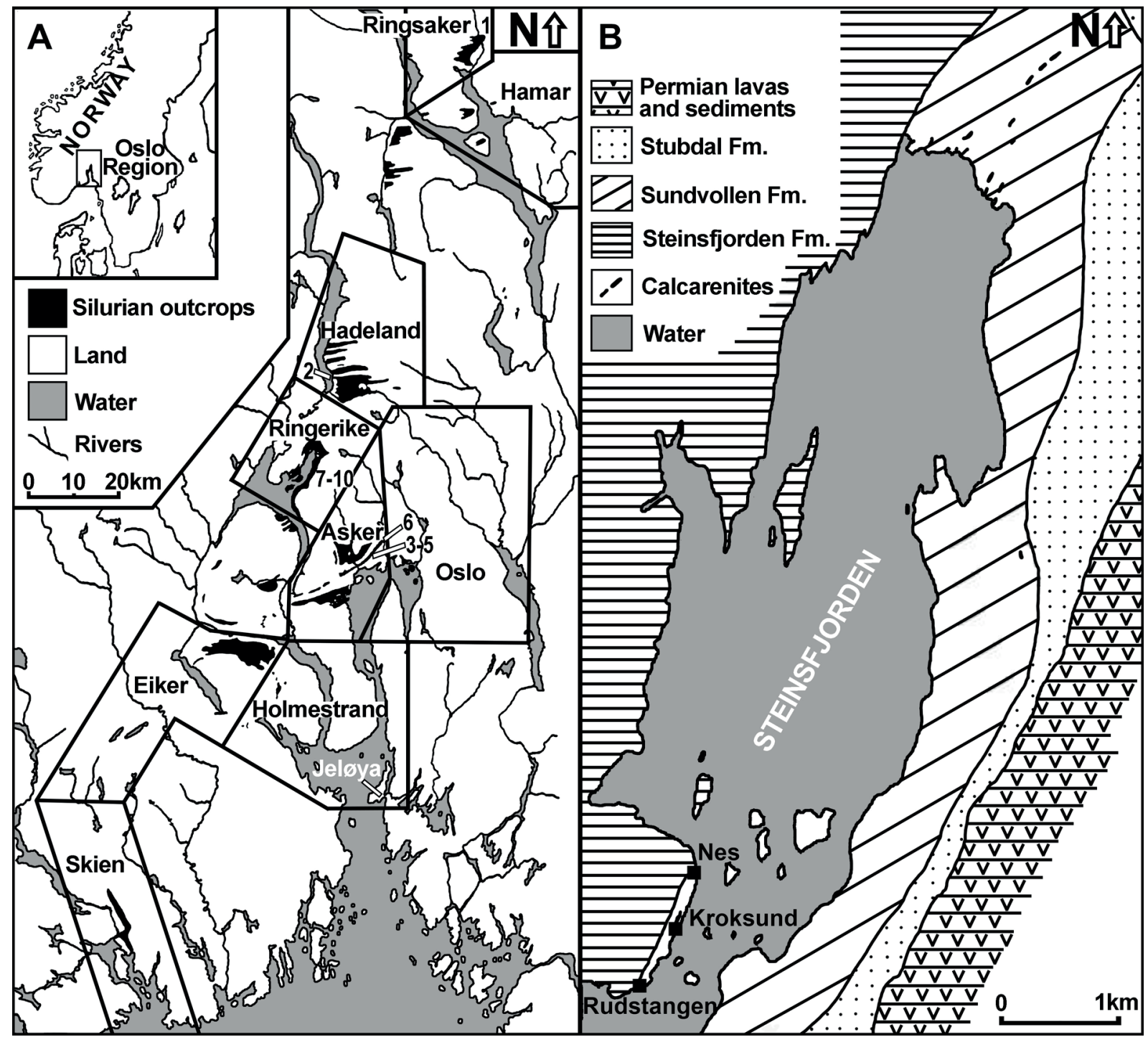

Figure 1. (A) Map of the Oslo Region modified from Worsley et al. (1983) showing the districts discussed in the text, as well as all Silurian outcrops in black. Numbers indicate the sampled localities within these districts: 1, Nes Peninsula (PMOGHA2 sample); 2, Bjellum 1 (PMO 234.229); 3-5, Gjettum Station 1 (PMO 234.230), Gjettum Station 7 and 8 (PMO 234.231); 6, Øverland 1 (PMO 234.232); 7-10, 9g sample from Steinsfjorden Formation of Turner \& Turner (1974), Sundvollen (PMO 231.150), Kroksund (PMO 234.233), and other samples from lower Sundvollen Formation described here, as well as the calcarenite samples described in Turner \& Turner (1974) and Davies et al. (2005a). (B) Geological map of the area surrounding Steinsfjorden (Ringerike district) based on Turner \& Turner (1974) showing vertebrate-producing localities (squares) and the distribution of calcarenites in the area.

considered to be situated slightly lower stratigraphically (Heintz, 1969), although still above the base of the Ringerike Group. Articulated fossils of the osteostracan Hemicyclaspis kiaeri have been reported from farther south at Jeløya (Kiær, 1931; Heintz, 1939). These specimens come from the Holmestrand Formation toward the top of the Ringerike Group (Turner, 1974b). According to Heintz (1974), the similarity of this taxon to the British $H$. murchisoni indicates an early Přidoli age for these strata (see also Calner et al., 2013; Turner et al., 2017).

Studies of articulated specimens have had a profound impact on our understanding of early vertebrate morphology and evolution, but provide little in terms of detailed biostratigraphy, global correlation and diversity patterns. Detailed stratigraphical and geographical distribution studies require a much more expanded set of data than the isolated occurrences of well-preserved articulated specimens. The usually more abundant record of disarticulated scales and fragments of dermal bone, recovered by acid preparation, provides greater potential for high-resolution biostratigraphy and correlations (Long, 1994; Blieck \& Turner, 2000; Märss et al., 2007; Märss \& Männik, 2013). Thelodonts and, more continuously so, acanthodians have been shown to be particularly useful in this context because their taxonomically identifiable isolated scales are widespread in the Silurian and Devonian of most palaeogeographical provinces (e.g., Turner, 1997, 1999; Valiukevičius, 1998, 2005; Märss et al., 2006, 2007; Hairapetian et al., 2016; Ferrón et al., 2018). In recent years, detailed 
studies of osteostracans and anaspids have provided new taxonomical frameworks for identification of fragmentary material from these groups as well, which also contribute to the resolution of their stratigraphical and geographical distribution (Blom et al., 2002; Märss et al., 2014; Turner et al., 2017).

Disarticulated vertebrate microremains have been found in both a wider geographical area and temporal range in the Oslo Region. The majority of this material has been given to one of the current authors by the various people active in the area over the years (see Materials and methods). The first detailed description of thelodont scales from the Ringerike area was performed by Turner \& Turner (1974), but thelodont scales have been reported in other works: from the Fleskum Kalkstein (upper part of the Malmøya Formation) probably spanning the Llandovery-Wenlock boundary (Turner, 1984, 1999); the late Wenlock Steinsfjorden Formation (Gross, 1967; Turner, 1984, 1999); and in a series of calcarenite beds in the overlying Sundvollen Formation of the lower Ringerike Group (Kiær, 1924; Størmer, 1954; Turner, 1974a, 1984, 1999). Fragmentary remains of anaspids have also been briefly described as a complement to the articulated specimens of the Rudstangen Fauna (Blom et al., 2002).

Following the thesis work in the Ringerike district of N. S. Davies (2003), Davies et al. (2005a, 2005c, 2006) gave new interpretations of the geological setting and commented on the significance of the vertebrates found within the group. They concluded that "a large number of the agnathan scales found in the Ringerike Group and associated sediments are 'facies fossils' rather than having a reliable biostratigraphic signature" (Davies et al., 2005a, p. 194). However, the identifications of the figured thelodont scales (Davies et al., 2005a, fig. 3) are in need of revision. Furthermore, the cited vertebrate occurrences that give the largest temporal discrepancies were briefly mentioned in Vergoossen (2002), and this was accompanied by the following caveat in his $\mathrm{PhD}$ thesis: "The 'Ringerike' sample, mentioned here and in later Chapters, may have received a wrong label and derive from the Öved Sandstone Formation exposed at Ramsåsa quarry [Sweden]..." (Vergoossen, 2003, p. 26). This is further strengthened by the faunal composition of the sample, as well as the preservation and red colour of the remains that are identical to samples from Ramsåsa (OB \& HB, pers. obs. 2018). Given this uncertainty, the inclusion of data from this sample in biostratigraphical investigations of the Oslo Region are strongly discouraged.

In this study, we review and revise all previous reports of Silurian vertebrate microremains from the Oslo Region, and present previously unpublished vertebrate microfossils from the palaeontological collections of Naturhistorisk museum (now incorporating the former Paleontologisk museum) in Oslo, Norway, and
Naturhistoriska riksmuseet in Stockholm, Sweden. This is done in conjunction with a review of the stratigraphical and geological context of the described samples, with the aim of clarifying the taxonomy of vertebrate microremains from the Oslo Region and discuss previous biostratigraphical conclusions. Furthermore, the articulated thelodont specimens from the classic Rudstangen locality are figured and described here for the first time.

\section{Materials and methods}

The present study includes isolated microscopic vertebrate remains from 14 samples collected from different areas and horizons within the Oslo Region (see below), which were recovered predominantly during acid-processing of marine calcareous samples for conodonts. We also re-assess taxonomic designations based on published data (Turner, 1974b, 1984; Davies et al., 2005a), and describe here a few of the articulated thelodont specimens from Norway that were collected by Johan A. Kiær in the early $20^{\text {th }}$ century.

The stratigraphically oldest sample labelled as PMOGHA2 in the PhD-thesis of Susan Turner was collected in the early 1960s by György Hamar from the Helgøya Quartzite in Nes Peninsula, southern Norway, and was later passed on to one of the authors (ST) via Natascha Heintz in 1983. Unfortunately, the majority of specimens were lost during transport due to slide breakage, and only a few scales remained for analysis by Turner (1984). These remaining specimens have not been found and were not available for the current study, but are described based on previous illustrations in Turner (1984) for completeness (Appendix Fig. 1G-I). In the 1960s, Richard J. Aldridge found thelodont scales associated with conodonts in samples collected by Snorre Olaussen from the Bjellum 1 (sample PMO 234.229) and Gjettum Station 1 (sample PMO 234.230) localities. These samples were described and figured together with Gjettum Station 7 and Gjettum Station 8 (both in one slide labelled PMO 234.231), as well as Øverland 1 (PMO 234.232) samples by Turner (1984) (see Appendix), and have been made available for re-examination in this study.

The PMO 234.233 sample comes from the Kroksund locality, geographically in between Rudstangen and Nes (Fig. 1B). Sample PMO 231.150 was collected by G. Hamar at Sundvollen and has a label in Norwegian translating to "et. 9-10; $0.5 \mathrm{~m}$ under fish layer". All of the samples described above (prefixed PMO) are stored at the Natural History Museum in Oslo (Norway). The material described by Turner \& Turner (1974) was sampled by Peter Turner at around the same time during his $\mathrm{PhD}$ studies in the Ringerike area and described 
by ST. These samples are stored at the University of Leicester, Department of Geology, but only the remainder of sample 295 (LEIUG 123381) was available for detailed examination in this study. Samples LEIUG 123382 (labelled 9g Ringerike ST1) and LEIUG 123383 (labelled Ringerike grey Sst ST2) come from the same area and interval and are stored together with sample 295 at the University of Leicester.

Four slides (NRM-PZ C6061-6064) labelled "Ringerike $9 \mathrm{~g}$ " were found in the collections of the Natural History Museum in Stockholm. One of the slides (NRM-PZ C6062) has the additional labelling "Bendix-Almgren 1957" and an Estonian text translating to "Sample straight from above Ceph[alaspids]", which most likely indicates the collector, year and locality if it refers to the classic Rudstangen Fauna. Another slide (NRM-PZ C6061) has the additional information "Rudstangen" written on the label, probably indicating the locality. Unfortunately, no more details are known for these samples, but they are most likely in close association with the fish-bearing layers of Rudstangen.

All of the figured microremains were coated in a goldpalladium alloy and imaged using a scanning electron microscope (SEM) at the Evolutionary Biology Centre, Uppsala University, with a Zeiss Supra 35VP.

Several articulated thelodonts (approximately 50 specimens) form part of the large collection of fish fossils from the Rudstangen fish locality (Fig. 1B) in Ringerike (Kiær, 1924), which is housed at the Natural History Museum in Oslo. We chose the five best-preserved thelodont specimens for description in this study. The fish assemblage originates from a horizon with fine-grained, dark greyish-green sandstone from the lowermost part of the Sundvollen Fm. (Fig. 2), which ranges in age from late Wenlock to early Ludlow. The collection was mainly assembled during major excavations made in 1909-1913 led by J. Kiær (Kiær, 1924), and is by far dominated by

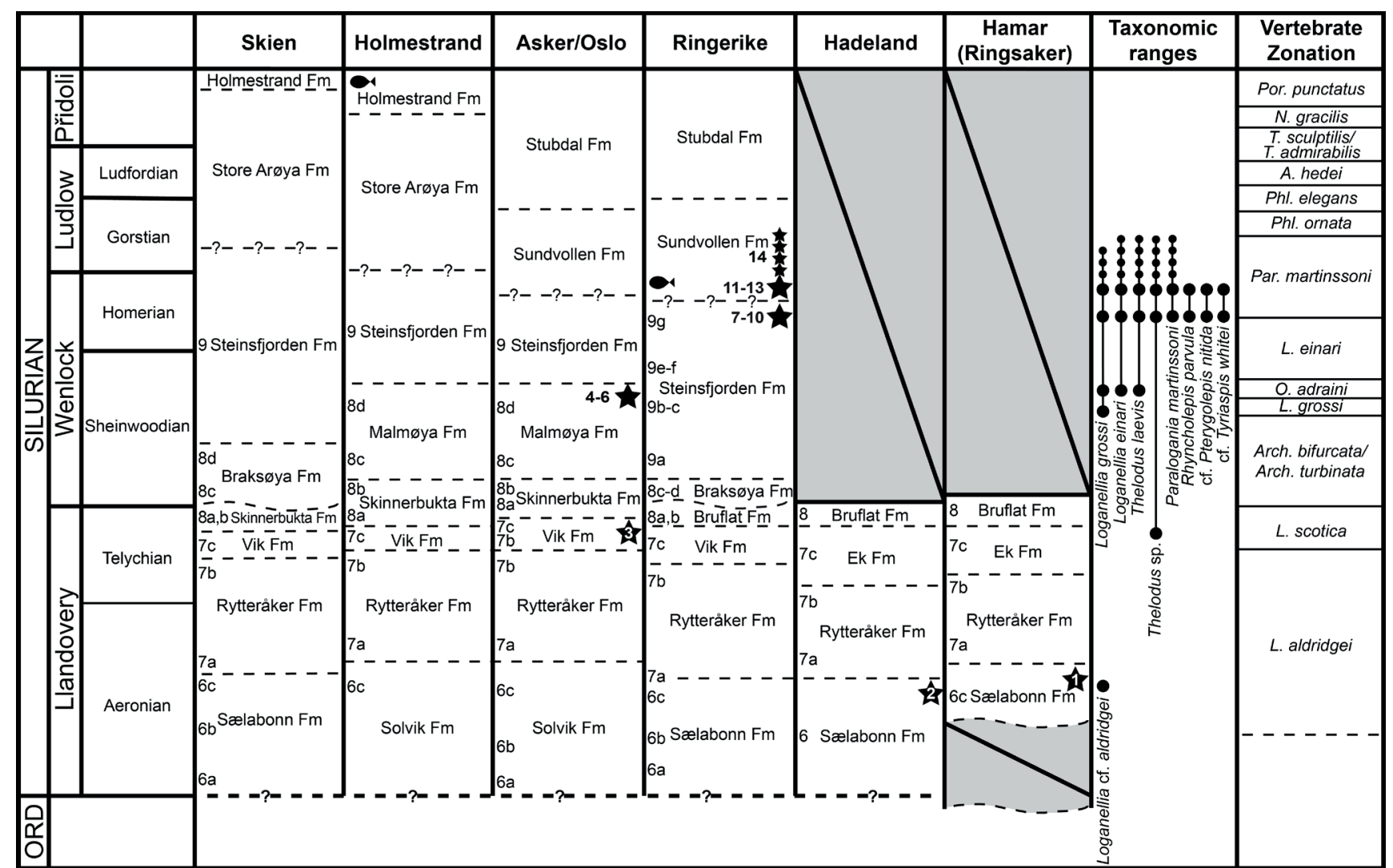

Figure 2. Simplified stratigraphical columns of the districts discussed in the text with formation names and the old 'Etagen' numbers 6-9, the ranges of vertebrate taxa reported in this study, as well as a rough correlation to the Generalized Vertebrate Zonation presented in Märss \& Männik (2013). The numbers, large stars and large circles roughly indicate the stratigraphical position of samples and vertebrate occurrences, and the small stars and circles reflect the uncertain stratigraphical distribution of the several calcarenite samples. 1 - PMOGHA2 sample; 2 PMO 234.229 (Bjellum 1); 3 - PMO 234.230 (Gjettum Station 1); 4-6 - PMO 234.231 (Gjettum Station 7 and 8) and PMO 234.232 (Øverland 1); 7-10 - samples LEIUG 123382, NRM-PZ C6061, NRM-PZ C6063, and NRM-PZ C6064; 11-13 - samples PMO 231.150 (Sundvollen), PMO 234.233 (Kroksund), and NRM-PZ C6062 samples; 14 - calcarenite samples of Turner \& Turner (1974), Davies et al. (2005a) and in this study. Fish outlines show the approximate level of the Rudstangen Fauna (Sundvollen Formation) and the osteostracan remains from Jeløya (Holmestrand Formation). Ages and formation boundaries taken from Worsley et al. (1983: fig. 4, stratigraphy of the Ringsaker district inferred from the text), Baarli \& Johnson (1988), Davies et al. (2005a), Calner et al. (2013), and references presented in the text. 
the much more well-known anaspids (Blom et al., 2002) and osteostracans (Heintz, 1939). For this study, the thelodont specimens have been observed by $\mathrm{OB}, \mathrm{HB}$ and $\mathrm{TM}$, and photographed under alcohol for better contrast, using a Nikon DS-Fil camera mounted on a Leica MZ95 stereomicroscope.

Institutional abbreviations: University of Leicester Department of Geology - LEIUG; Natural History Museum (now incorporating the former Paleontologisk Museum), Oslo (Norway) - PMO; Swedish Museum of Natural History, Palaeozoological collections, Stockholm (Sweden) - NRM-PZ.

\section{Geological and stratigraphical
framework}

The Oslo Region in Norway includes Lower Palaeozoic sedimentary rocks ranging in age from Cambrian to late Silurian, as well as volcanic and plutonic rocks of Late Palaeozoic age, that are surrounded by Precambrian rocks to the east and west, and limited by the Caledonian nappes to the north (Calner et al., 2013). The Silurian succession (Fig. 2) is approximately $1950 \mathrm{~m}$ thick and ranges in age from Llandovery to Přidoli (see Calner et al., 2013 and references therein). The strata consist of marine shales and limestones that transition to nonmarine sedimentary rocks and red-beds, reflecting a complex tectonic and depositional history of a foreland basin developing in front of the Norwegian Caledonides (Worsley et al., 1983; Baarli, 1990; Davies, 2003; Calner et al., 2013).

The first detailed description of the marine Silurian faunas and sedimentary successions of the Oslo Region was presented by Kiær (1908), in which he refined the previous division of the sequence into "Etagen" introduced by Kjerulf \& Dahll (1857). Kiær (1908) divided the sequence into "Etagen" 6 to 9 (see Fig. 2) and assigned the overlying red-beds to "Etage" 10 (Worsley et al., 1983). This work was followed by a series of reviews and slight revisions of the Silurian sequence, but most subsequent studies generally accepted the original stratigraphical framework (see Worsley et al., 1983 for a comprehensive review). Following a survey by Bassett \& Rickards (1971), Worsley et al. (1983) recognised the need for a revision of the stratigraphical scheme of the Oslo Region and proposed a lithostratigraphical framework for the entire succession. This resulted in divisions of the Silurian in the area into a number of formations and members reflecting the north-to-south differences in depositional setting (Fig. 2). Several important contributions to the detailed stratigraphy and interpretations of depositional environments have been made after this (e.g., Baarli, 1990; Baarli et al., 1999; Davies, 2003; Davies et al., 2005a, b, c, 2006).
The PMOGHA2 sample comes from the Helgøya Quartzite Member in the Ringsaker district (Fig. 1A), which is a local member described by Skjeseth (1963). This unit constitutes the entire Sælabonn Formation in the Ringsaker, Hamar and Toten districts, and is composed of a medium to thickly bedded sandstone with shaly partings that grade into interbedded sandstones and shales with limestone intercalations toward the top (Worsley et al., 1983). The sample presented here was taken in one of these red calcareous partings by G. Hamar in the 1960s at Torsæter Bridge, Hedemark, where the shales are "crowded with worm trails" and sandstones exhibit load structures (Skjeseth, 1963). The Quartzite rests with a marked unconformity on the upper Middle Ordovician Mjøsa Limestone (Opalinski \& Harland, 1981) and is succeeded by the "Pentamerus Limestone" of the Rytteråker Formation (Skjeseth, 1963). The Helgøya Quartzite Mbr. is correlated with the Phacops Quartzite of Sweden and is placed in Kiær's "Etage" 6c, which Aldridge \& Mohamed (1982) and Worsley et al. (1983) equated with the upper Solvik and Sælabonn formations of the Asker and Ringerike districts, respectively. This would place the Helgøya Quartzite Mbr. of the Ringsaker district in the Aeronian (Idwian in Worsley et al., 1983; Fig. 2). Opalinski \& Harland (1981) discussed the Helgøya Quartzite Mbr. and showed its geographical distribution. The disconformity below the unit represents a "spectacular palaeokarstic surface", which was infilled by the coarse basal sandstone of the Helgøya Quartzite Mbr., and subsequently by limestone. In the northern districts, much of the lowermost Silurian strata are missing, while in the southern districts (e.g., Ringerike district) the unconformity is less substantial (Fig. 2). Here, the lower parts of Sælabonn Fm. instead contains faunas indicative of the Rhuddanian according to Thomsen et al. (2006). The details that are available suggest that the Helgøya Quartzite Mbr. is part of a transgressive group of sediments including some of shallow-water littoral and possibly brackish-water origin (Worsley et al., 1983).

The Bjellum 1 road section sample comes from a calcareous band within the uppermost part of the Sælabonn Fm. in the Hadeland district (Figs. 1A \& 2). The thelodont-bearing horizon is $5.45 \mathrm{~m}$ below the base of the Borealis-kalk of the overlying Rytteråker Fm., near the mid-/upper Llandovery boundary (Baarli et al., 1999). Hence, this sample is probably of late Aeronian age (Idwian in Worsley et al., 1983), and subsequently largely equivalent to the PMOGHA2 sample described above. The sediments are interpreted as being of very shallow-water marine origin with interdigitating deltaic sandstone wedges (Worsley et al., 1983).

Thelodont scales were recovered from a sample from a limestone horizon within the Vik Formation at the locality Gjettum Station 1, $22.25 \mathrm{~m}$ up a measured section in the railway cutting west of Gjettum Station in the Asker district (Figs. 1A \& 2). Conodonts (Turner, 
1984) and other palaeocommunities (Baarli et al., 1999) indicate a Telychian age for the sample. The Vik Fm. is best exposed in the Ringerike district, where it is approximately $80 \mathrm{~m}$ thick and has a tripartite division forming three members: 1 , the lower Storøysundet Member consisting of red shales with minor bioclastic limestone lenses, calcareous nodules and greenish-grey shale interbeds; 2, the middle Garntangen Member composed of thinly bedded limestones and calcareous nodules with minor greenish-grey marls; 3 , the upper Abborvika Member of greenish-grey to red shales with interbedded finely nodular limestones (Worsley et al., 1983). South of Oslo, on Malmøya, Worsley et al. (1983) described the Vik Fm. as consisting of irregularly varying proportions of greenish-grey shales and marls with finely nodular limestones, as well as occasional thin intraformational conglomerate horizons. The vertebrateproducing sample presented here comes from the Asker area, which is positioned in between the Ringerike and Malmøya areas (Fig. 1A), and the deposits are here considered to be intermediates of the ones mentioned by Worsley et al. (1983). The depositional environment of the Vik Fm. is considered to be deeper than the preceding Rytteråker Fm., with greater, although only fine-grained, clastic input (Worsley et al., 1983; Baarli et al., 1999).

The type section of the Malmøya Fm. can be found in Gjettum, where the lower part is composed of varying proportions of continuous, nodular and lenticular limestone horizons with interbedded shales that grade into thicker, massively bedded biosparitic limestones, which in turn grade into coral and stromatoporoid biostromes and biosparrudites toward the top (Worsley et al., 1983). The samples from localities Gjettum Station 7 and Gjettum Station 8 in the Asker district (Fig. 1A), as well as Øverland 1 north of Oslo, come from the massive limestone of the upper Malmøya Fm. (Fig. 2). The Gjettum Station 7 sample was taken from the base of this limestone unit in a coral conglomerate resting disconformably on sediments below, while the Gjettum Station 8 sample comes from a forest behind Gjettum Quarry and a slightly higher stratigraphical position. The Øverland 1 sample came from old Ringerikesveien, from a horizon about $8 \mathrm{~m}$ below a Favosites bank at the top of a sequence of the bioclastic limestone in this area. The Malmøya Fm. as a whole is interpreted to reflect shallowing from the storm-generated limestoneshale alternations to massive limestones of prograding carbonate shoals (Worsley et al., 1983). The faunas within the formation generally point to a Wenlock age for the deposits (Baarli et al., 1999), and the vertebrate-producing limestone in the Asker district has been correlated with the middle part of the Steinsfjorden Fm. ("Etage" 9b-c in Fig. 2) in the Ringerike area (Worsley et al., 1983).

Similar to many other formational boundaries of the Silurian strata in the Oslo Region, the lower boundary of the Steinsfjorden Fm. is diachronous, getting younger toward the south (Worsley et al., 1983;
Davies, 2003). This formation corresponds to "Etage 9" of Kiær (1908), and some of the previously reported thelodont scales from the Ringerike district come from the thin limestones and shales of the uppermost part in this area (Turner \& Turner, 1974), which was named Ranberget Member by Worsley et al. (1983). The four samples from the collections of NRM-PZ labelled "Ringerike 9g" possibly derive from these strata (Fig. 2 ). This member is composed mainly of greenish-grey marls with thin limestone beds and nodular horizons, and the upper boundary is gradationally passing into red mudstones and sandstones of the Ringerike Group (Worsley et al., 1983). Worsley et al. (1983) interpreted the mixed carbonate and mud lithologies as supratidal, intertidal and restricted subtidal environments with a sediment cycle representing small-scaled regressions and transgressions. The favositid bioherms and biostromes in the upper part of the formation indicate a largerscale transgression and periods of more normal marine conditions, which is reflected throughout the Oslo Region, while the shift to the clastic Ringerike Group represents a subsequent regression (Worsley et al., 1983). According to Worsley et al. (1983), studies of ostracod and thelodont faunas from the upper part of Steinsfjorden Fm. (Gross, 1967; Martinsson, 1969; Turner \& Turner, 1974) suggest a late Wenlock age for these strata. This is also supported by the correlative bentonite beds in the Steinsfjorden Fm. of Ringerike (Hetherington et al., 2011). Collectively then, this gives support to the notion that the transition from marine to red-bed deposits approximates the Wenlock/Ludlow boundary in some areas of the Oslo Region. In the southern districts (e.g., Skien), the marine deposition of Steinsfjorden Fm. continued for a longer time compared to the northern areas where it is replaced by the Ringerike Group (Davies et al., 2005a; Calner et al., 2013).

The mostly non-marine red beds of the Ringerike Group conformably overlie the Steinsfjorden Fm. with a gradational contact in the Ringerike, Asker, Holmestrand, Eiker and Skien districts (Worsley et al., 1983). The red beds were assigned to "Etage 10" by Kiær (1908), who suggested a Devonian age for these strata. However, later studies of fossil faunas placed the group as upper Silurian, although a detailed age determination has proven difficult (see discussion in Worsley et al., 1983 and in later sections). Turner (1974b) divided the Ringerike Group into the Sundvollen and Stubdal formations, representing the lower and upper part in the type area of the Ringerike district. The Sundvollen Fm. is composed of red blocky siltstones and mudstones, and fine-grained sandstones interpreted as deposited in a broad, muddy, coastal plain environment (Davies et al., 2005a). The Rudstangen Fauna was found in the lower part of this formation (Fig. 2) at the Rudstangen locality (Fig. 1B), and is the only siliciclastic part with body-fossils. The specimens from this locality were recovered approximately $10 \mathrm{~m}$ above the base of the whole Ringerike Group, in a thin lens of greenish-grey, 
fine-grained sandstones (see Turner \& Turner, 1974). Articulated vertebrates from the close-by locality of Nes (Fig. 1B) were recovered in a similar lithology, although from a slightly lower stratigraphical level (see Heintz, 1969). The PMO 231.150 sample presented here was taken $0.5 \mathrm{~m}$ below this fish-bearing horizon, while the PMO 234.233 sample comes from the Kroksund locality geographically in between Rudstangen and Nes (Fig. 1B). All of the other microremains from Sundvollen Fm. described by Turner \& Turner (1974), Davies et al. (2005a), and in this work come from grey, mediumgrained, and lens-shaped calcarenites that occur within the formation (Fig. 2). Turner (1974a) demonstrated a strong bimodal depositional current for the calcarenites, and interpreted them as tidal deposits with a maximum water depth of $0.9 \mathrm{~m}$. However, Davies (2003) interpreted the often laterally restricted calcarenite deposits as redeposited event horizons, possibly caused by monsoons or tsunamis considering the subequatorial position of the Oslo Region in a tectonically active area during late Silurian times. Indeed, Silurian high-energy deposits of potential tsunami origin have been described in carbonates of the tectonically associated Baltic Basin (Jarochowska \& Munnecke, 2015). The Sundvollen Fm. also includes the 10-15 m-thick Dronningveien Siltstone Member toward the top, but it is only found in the Ringerike district (Davies et al., 2005a).

The Stubdal Formation is dominated by sandstones with intraformational conglomerates reflecting braided fluvial successions (Turner, 1974b; Worsley et al., 1983; Davies et al., 2005a). This formation only occurs in the northern part of the Oslo Region, where it comprises the youngest sediments of the group (Davies et al., 2005a).

The Ringerike Group is similar in the Asker district, but generally finer grained and much thinner (Turner, 1974b). The strata continue to thin southwards and there is a conspicuous absence of Ringerike Group strata south of the Holmestrand district (Fig. 1A) until it is found again farther to the south in the Skien district (Davies et al., 2005a). Turner (1974b) defined the Holmestrand Fm. as part of the Ringerike Group outside of the type area. However, Davies et al. (2005a) deemed its definition as too broad and separated the Store Arøya Formation from its lower part in areas south of Oslo. This formation either interfingers with, or conformably overlies, the limestones of Steinsfjorden Fm., indicating an interfingering of Ringerike Group strata with the underlying carbonates (Davies et al., 2005a). Davies et al. (2005a) described the Store Arøya Fm. as consisting of often massive, fine- to coarse-grained sandstones with some thin silt or mudstone horizons. Interestingly, petrological and palaeocurrent studies indicate a different provenance and direction of transport for the Store Arøya Fm. compared with the northern equivalent Stubdal Fm. (Davies, 2003; Davies et al., 2005a). The redefined Holmestrand Fm. constitutes the upper part of the group and consists of medium- to coarse-grained, calcareous- cemented sandstones with minor extraformational quartzite conglomerates (Davies et al., 2005a). It occurs only in scattered outcrops, and is described by Davies et al. (2005a) to conformably overlie the Store Arøya Fm., as the lithologies of the latter gradationally give way to the former. However, in many areas the formation is entirely missing due to later erosion (Davies et al., 2005a). Fossils indicate a more marine influence for the Holmestrand $\mathrm{Fm}$. and the sediments are interpreted as a beach depositional system (Davies, 2003; Davies et al., 2005a). The previously mentioned articulated osteostracans described by Heintz (1974) from Jeløya (Figs. 1A \& 2) come from these strata in the Holmestrand district, and provide a conclusive Přidoli age for the uppermost Ringerike Group according to Davies et al. (2005a) and Calner et al. (2013).

\section{Vertebrate Assemblages}

\section{Llandovery}

Aeronian (Sælabonn Fm., Fig 2: numbers 1 and 2)

Following the stratigraphical scheme presented in Figure 2 , and the overall similarity of the scale assemblages, the PMOGHA2 sample (Helgøya Quartzite Mbr., Nes Peninsula) and the Bjellum 1 sample from the Sælabonn Fm. will be described together. The 29 rather friable, grey scales in the Bjellum 1 sample (Fig. 3A-F) are here referred to Loganellia cf. aldridgei based on their overall morphology (see Systematic palaeontology). The majority display typical trunk scale morphologies, while one is probably a transitional scale. Unfortunately, the original sample from Nes Peninsula (PMOGHA2) has not been found and can only be reported based on the three scales illustrated by one of us (Turner, 1984: figs. 5.2G-I). She identified these scales as Loganellia sp. and here we assign them to $L$. cf. aldridgei.

\section{Telychian (Vik Fm., Fig. 2: number 3)}

The Telychian age of the sample from the Vik Fm. at Gjettum Station 1 (PMO 234.230) is confirmed by conodonts (Turner, 1986) and other palaeocommunities (Baarli et al., 1999). The sample is exceptional, both in terms of its scale content and by its relatively wellpreserved state. The four thelodont scales were all identified as Thelodus parvidens by Turner (1986) and included two trunk scales (Fig. 3G, H), as well as one bicostatiform (Fig. 3I) and one trilobatiform (Fig. 3J) scale variant. These are all similar to the natural assemblage of T. parvidens, which is more typical of the Ludlow to early Downton of Europe and eastern Canada (e. g., Turner, 1986; Märss et al., 2007). However, another early Thelodus taxon is Thelodus laevis, which is reported from the mid-Wenlock of the associated Baltic Basin (e.g., Märss, 1986; Fredholm, 1990), and occurs in younger strata of the Oslo Region (see below). The 


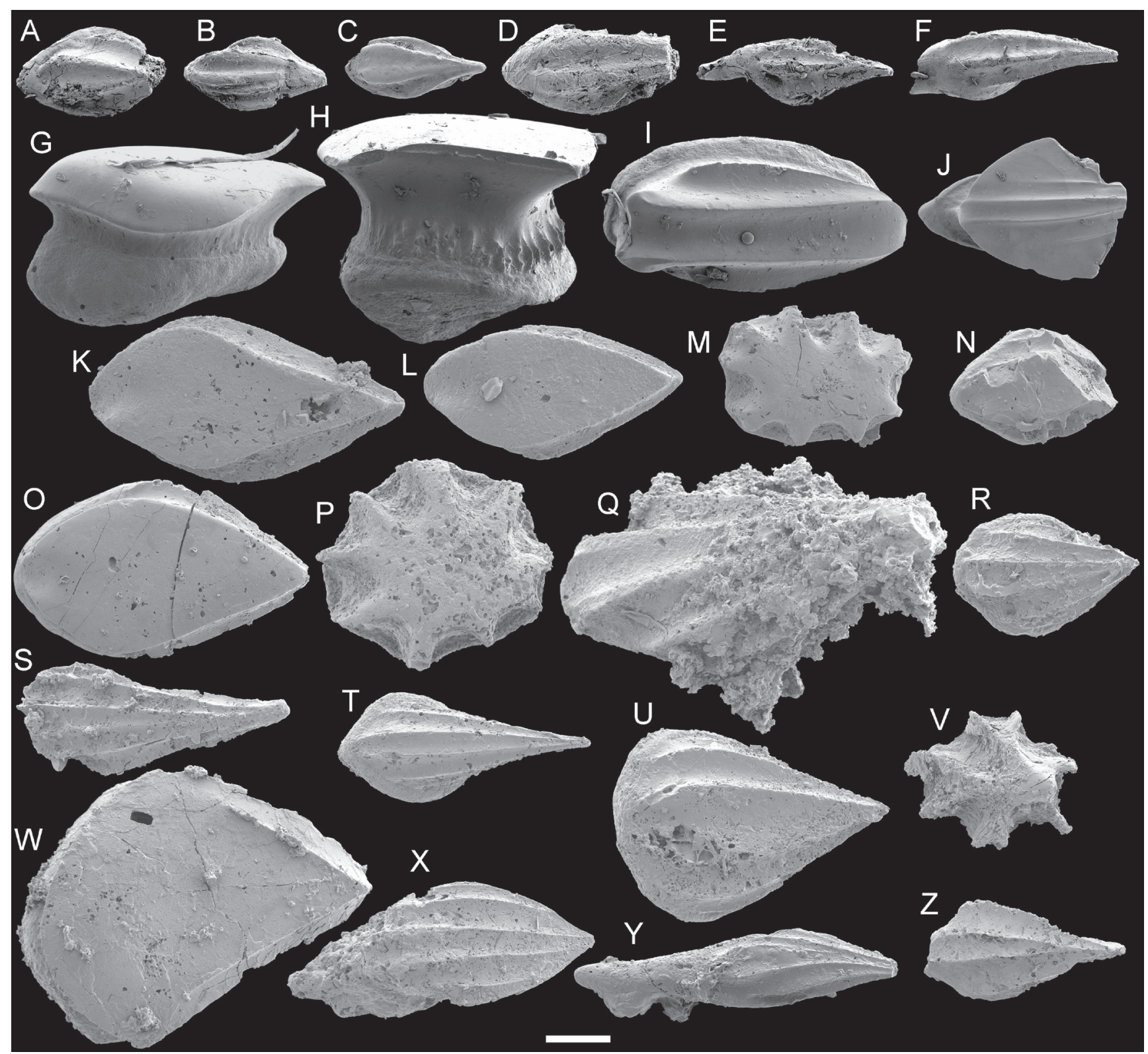

Figure 3. (A-F) Loganellia cf. aldridgei (PMO 234.229A-F) from Bjellum 1 (sample PMO 234.229). (G-J) Thelodus sp. (PMO 234.230 A-D) from Gjettum Station 1 (sample PMO 234.230) including the bicostatiform (I) and trilobatiform (J) scale morphology. (K-L) Loganellia grossi trunk scales (PMO 234.231A-B) from Gjettum Station 7 (sample PMO 234.231). (M-O) L. grossi head (M; PMO 234.231C), transitional (N; $P M O$ 234.231D), and trunk (O; PMO 234.231E) scale from Gjettum Station 8 (sample PMO 234.231). (P-T) Loganellia einari in the Øverland 1 sample (PMO 234.232) including head (P; PMO 234.232A), transitional (Q; PMO 234.232B), trunk (R-S; PMO 234.232C-D), and posterior (T; PMO 234.232E) scales. (U) L. grossi trunk scale (PMO 234.232F) from Øverland 1. (V-Z) Thelodus laevis head (V; PMO 234.232G), trunk (W-X; PMO 234.232H-I), and posterior/pinnal ( $Y-Z ; P M O 234.232 J-K)$ scales from Øverland 1 . All scales are in external view except $G$ (lateral view) and $H$ (posterolateral view), and with anterior toward the left. Scale bar represents $0.1 \mathrm{~mm}$.

squamation of T. laevis incorporates scale morphologies similar to T. parvidens, including the otherwise typical flat-crowned scales with teardrop-shaped outlines that host vertical riblets along the posterolateral neck (see Gross, 1967: pl. 1, figs. 14-19), which is also seen in scales recovered from Wenlock strata of Gotland, Sweden (Gross, 1968: fig. 1B-C).

All the scales from sample PMO 234.230 are for now referred to as Thelodus sp. and mark the earliest appearance datum of this genus in Norway. They give additional support to the occurrence of thelodontids already in the Llandovery, as previously reported from England (Squirrell, 1958; Turner, 1973), Canada (Turner, 1986), the East Baltic (Märss, 1986) and Sweden (Fredholm, 1990).

\section{Wenlock}

Sheinwoodian (Malmøya Fm., Fig. 2: numbers 4-6) The Gjettum Station 7 sample from the Malmøya Fm. contained two grey loganelliid trunk scales (Fig. 3K, L), 
while 4 head scales, 1 transitional scale and six body scales (Fig. 3M-O) were recovered from the Gjettum Station 8 sample at a slightly higher stratigraphical level of the same formation. All of these scales fit within the scale set described for Loganellia grossi, which has been reported from middle to upper Wenlock strata of the Baltic area (Märss, 1996), northern Greenland (Blom, 2003), as well as the Russian and Canadian Arctic (Märss \& Karatajūtè-Talimaa, 2002; Märss et al., 2006, 2007).

The Øverland 1 sample toward the top of the Malmøya Fm. produced a total of 41 grey and chalky white thelodont scales, both of thelodontidid and loganelliid types (Fig. 3P-Z). Some of the scales are infilled with calcite and some look rotten with signs of algal or fungal attack. There are 15 loganelliid scales of rostral (Fig. 3P), trunk (Fig. 3Q, R) and fin scale (Fig. 3S, T) morphologies, that are here identified as Loganellia einari (although rostral scales can be hard to distinguish between different loganelliid taxa). This could indicate a slightly younger age for this sample compared with the Gjettum Station samples, because only L. einari and no L. grossi scales are found in younger samples of the Estonian sections (Märss, 1996). However, the two taxa occur together in samples from Gotland (Sweden) according to Märss (1996), and there is a single scale in the Øverland 1 sample identified as $L$. grossi (Fig. $3 \mathrm{U}$ ). Thelodontids are represented by head (Fig. 3V), trunk (Fig. 3W, X), as well as more posterior (Fig. 3Y) and fin scale (Fig. 3Z) morphologies that are all identified as T. laevis.

\section{Homerian}

$9 g$ horizon assemblage, Steinsfjorden Fm. (Fig. 2: numbers 7-10)

Turner \& Turner (1974) described one sample from "Etage" 9g of the Ranberget Mbr., Steinsfjorden Fm., in the Ringerike area (Worsley et al., 1983). They described thelodonts T. laevis (including T. schmidti, see Märss et al., 2007), T. trilobatus, "Logania" (=Paralogania) martinssoni, "Logania" taiti and Phlebolepis elegans from this sample. Ranberget Mbr. has also produced scales and plates of anaspids Pterygolepis nitida and Rhyncholepis parvula (Kiær, 1908; Blom et al., 2002). The identifications of the thelodonts, however, were partly revised with Logania taiti referred to either L. grossi or L. einari by Märss (1996) and Plax \& Märss (2011). Loganellia taiti was described from the $9 \mathrm{~g}$ sample by Turner \& Turner (1974), but no specimens from this sample were figured. The presence of Phl. elegans was overturned in Märss (1982: fig. 2), Märss (1986: fig. 46) and Märss (1990: table 16). The scale figured as $T$. trilobatus in Turner \& Turner (1974: fig. 3D) is here revised as Paralogania martinssoni based on similar scales of this taxon that have been described from the upper Wenlock Halla Formation of Gotland by Gross (1967: pl. 6, fig. 6) and Jarochowska et al. (2016, fig. 6O).

Sample LEIUG 123382 contains two fragmentary scales of the anaspid R.parvula (Fig. 4A) as well as 18 thelodont scales. The majority of the latter are relatively poorly preserved, making identification difficult. However, it is clear that three different forms are present: nine are more similar to thelodontidid scales (Fig. 4B, C); two are identified as the shieliid P. martinssoni (Fig. 4D, E); and three scales are identified as L. einari (Fig. $4 \mathrm{~F}-\mathrm{H}$ ).

As mentioned before, the samples labelled "Ringerike 9g" stored at the NRM-PZ are most likely associated with the Rudstangen Fauna, both geographically and stratigraphically. However, the beds of the Ranberget Mbr. at the top of Steinsfjorden Fm. show a gradational transition to the overlying strata in this area (Worsley et al., 1983). This may be further complicated by the tectonic displacements of strata, described in this area by Heintz (1969), and consequently these samples could derive from the Ranberget Mbr., but the faunal assemblage of the samples agrees with a close association with the Rudstangen Fauna from the overlying formation. Sample NRM-PZ C6061 contains numerous indeterminable fragments mostly of possible anaspid affinity, and a total of 59 identifiable vertebrate remains. Six fragments are of definite anaspid affinity, although their taxonomic identity is uncertain with the exception of Figure 4I, which is similar to Pt. nitida. The other specimens are thelodont scales: 17 Thelodus sp., 8 P. martinssoni (Fig. 4J), two scales (Fig. 4K, L) similar to the palmatilobate scales described as possibly being part of a Paralogania squamation by Märss (2006a: pl. 4, fig. 18), as well as 18 L. einari scales (Fig. 4M). This sample also contained eight osteostracan fragments. Five of these have an ornamentation composed of small, star-like tubercles (Fig. $4 \mathrm{~N}$ ) that are similar to those found in Tyr. whitei from the same area (OB, pers. obs. 2018). The remaining three are covered by longer ridges, both smoother in the less well-preserved fragment (Fig. 4O) and with some sharp and irregular, smaller ridges along the sides (Fig. $4 \mathrm{P}$ ) in the better preserved elements. The ridges are fairly tightly spaced, but pores are visible in between some of them. These specimens are here referred to Osteostraci gen. et sp. indet. The NRM-PZ C6063 sample contained approximately 50 indeterminable fragments of vertebrate affinity, two $R$. parvula fragments (Fig. 4Q), three T. cf. laevis (Fig. 4R), one possible L. grossi (Fig. 4S), eight L. einari (Fig. 4T), as well as three cf. Tyr. whitei fragments and one specimen referred to Osteostraci gen. et sp. indet. (Fig. 4U).

Sample NRM-PZ C6064 contains only four fragmentary remains (not figured), three are of indeterminable anaspid affinity and one is similar to the cf. Tyr. whitei described before.

The taxa reported from the Steinsfjorden Fm. in Davies et al. (2005a) based on the sample discussed by Vergoossen (2002), gave the largest discrepancies with regard to the vertebrate biostratigraphy established for the Silurian in that study. The fauna reported in that sample is more typical of late Ludlow to early Přidoli-aged strata (compare Märss \& Männik, 2013; Turner et al., 2017), with taxa such 


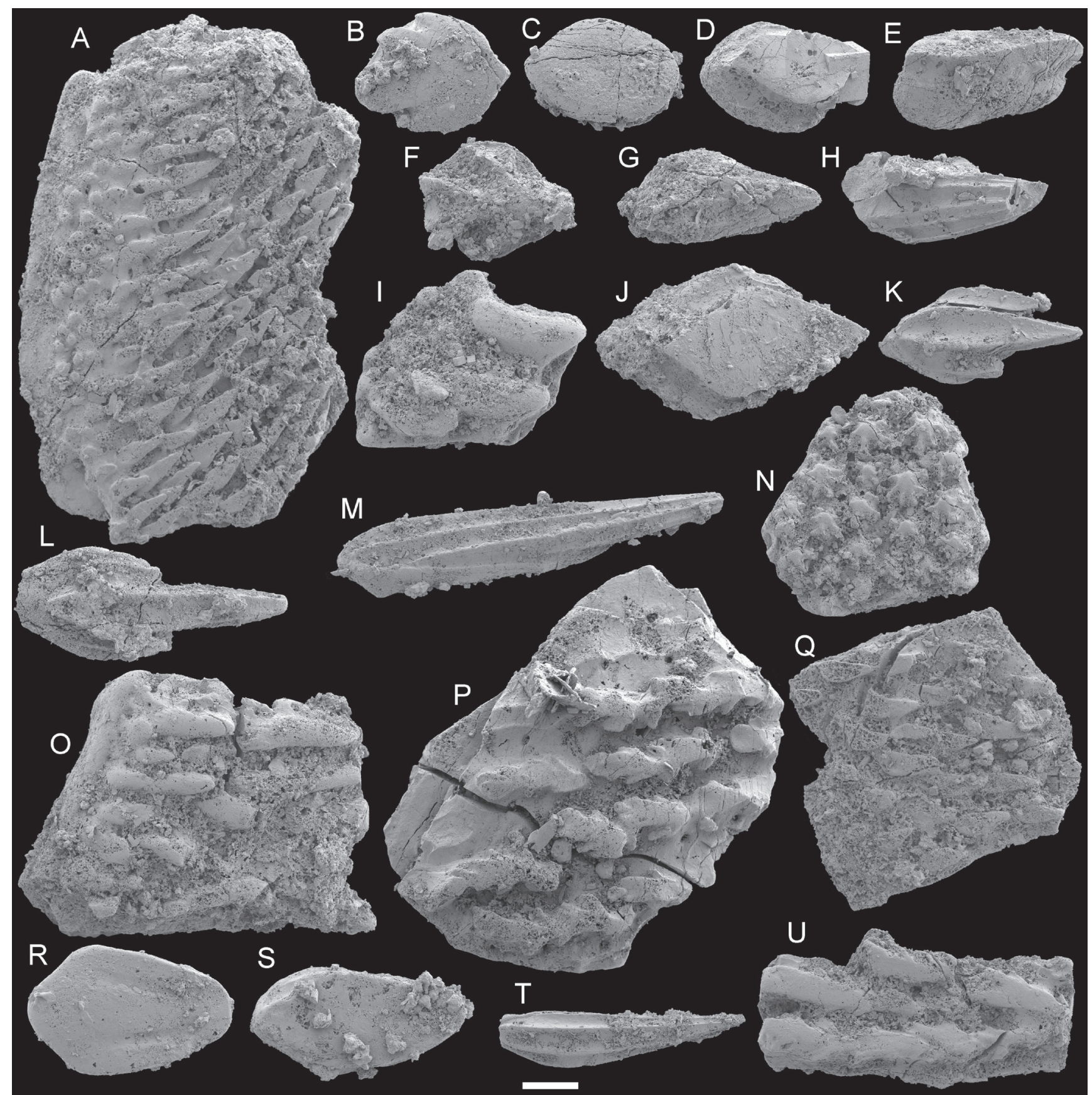

Figure 4. (A) Rhyncholepis parvula (LEIUG 123354). (B-C) Thelodus sp. (LEIUG 123355-123356). (D-E) Paralogania martinssoni (LEIUG 123357-123358). (F-H) Loganellia einari (LEIUG 123359-123361) from sample LEIUG 123382. (I) cf. Pterygolepis nitida (NRM-PZ C6065). $(J-L)$ P. martinssoni (NRM-PZ C6066-6068) including the palmatilobate scale variant (K-L). (M) L. einari (NRM-PZ C6069). (N) cf. Tyriaspis whitei (NRM-PZ C6070). (O-P) Osteostraci gen. et sp. indet. (NRM-PZ C6071-6072) from sample NRM-PZ C6061. (Q) R. parvula (NRM-PZ C6073). (R) Thelodus laevis (NRM-PZ C6074). (S) Loganellia grossi (NRM-PZ C6075). (T) L. einari (NRM-PZ C6076). (U) Osteostraci gen. et sp. indet. (NRM-PZ C6077) from sample NRM-PZ C6063. All specimens are in external view, except $E$ and $M$ (lateral view), with anterior toward the left. Scale bar represents $0.1 \mathrm{~mm}$.

as T. sculptilis, T. admirabilis, as well as the acanthodians Gomphonchus sandelensis and Radioporacanthodes biblicus (Davies et al., 2005a: Table 1 \& fig. 4). However, as mentioned before, this sample is likely mislabelled and instead derives from the upper Silurian of southern Sweden, which is plausible considering the typical fauna. The sample should therefore be excluded from any future investigations about vertebrate occurrences in the Silurian of the Oslo Region.
Gross (1968) figured a few vertebrate specimens from Ringerike 9g. These included two scales of $T$. laevis (Gross, 1968: figs. 1A and 2E ) and two osteostracans fragments (Gross, 1968: figs. 6F and 14E), the first of which is similar to the Osteostraci gen. et sp. indet. described above. 
Lowermost Sundvollen Fm. assemblages

(Fig. 2: numbers 11-13)

The well-known Rudstangen Fauna from the Rudstangen locality is composed of articulated specimens of the four anaspid taxa Pt. nitida, R. parvula, Pharyngolepis oblonga and Pharyngolepis? heintzi (Blom et al., 2002); osteostracans Ateleaspis tessellata, A. robusta, $\mathrm{H}$. gracilis and H. denisoni (Heintz, 1939); as well as a number of articulated thelodonts (Heintz, 1939; mentioned by Heintz, 1969). The fauna at the close-by Nes locality does not include any anaspids or thelodonts, but produced the same osteostracans with the addition of Ateleaspis sp. and Tyr. whitei (Heintz, 1967, 1969).

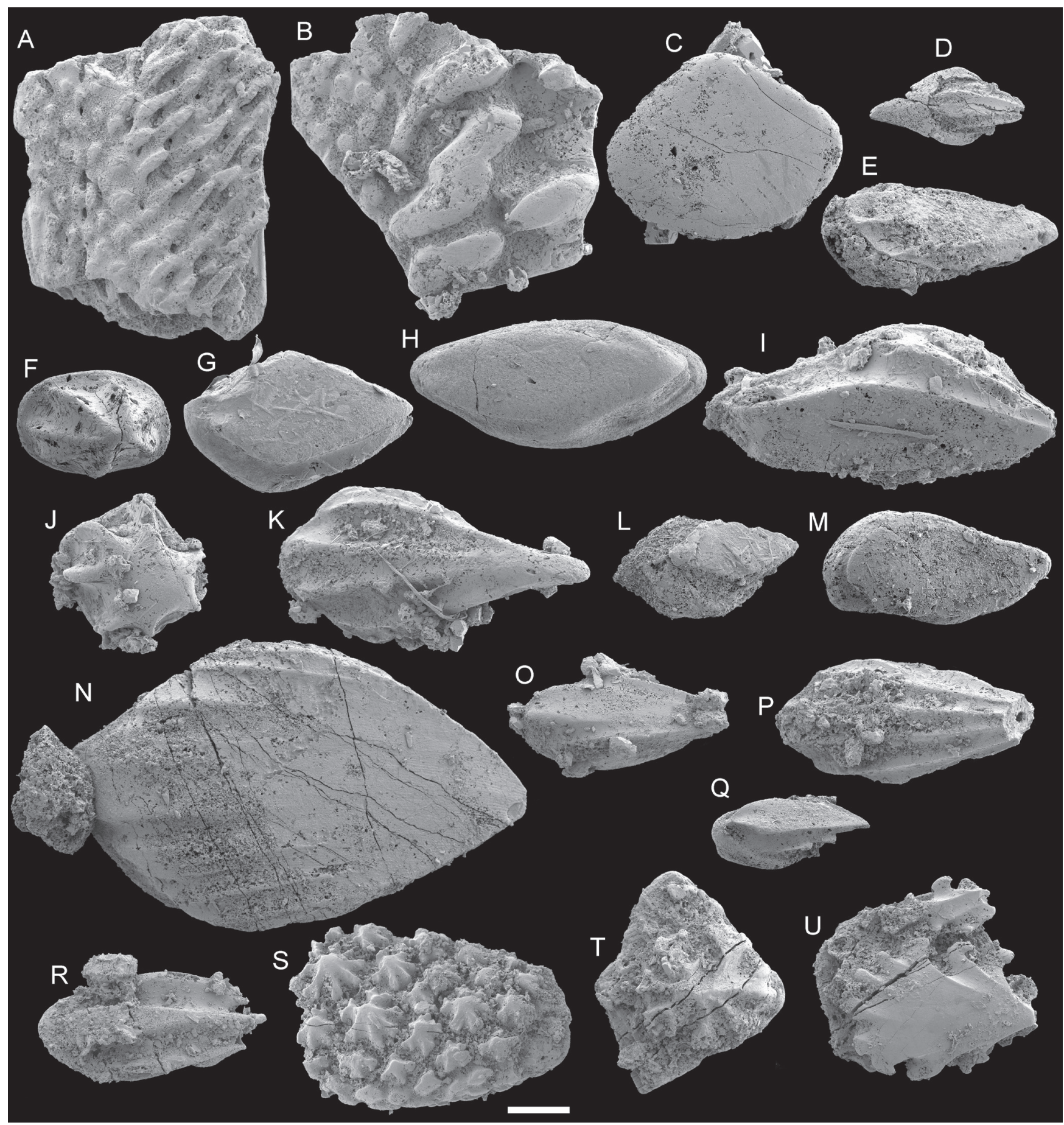

Figure 5. (A) Rhyncholepis parvula (PMO 234.150A). (B) cf. Pterygolepis nitida (PMO 234.150B). (C) Thelodus sp. (PMO 234.150C). (D) Paralogania martinssoni (PMO 234.150D). (E) Loganellia grossi (PMO 234.150E) from sample PMO 231.150. (F-I) L. grossi head (F; PMO 234.233A) and trunk (G-I; PMO 234.233B-D) scales. (J-K) Loganellia einari head (J; PMO 234.233E) and trunk (K; PMO 234.233F) scales. (L) P. martinssoni (PMO 234.233G). (M) Thelodus sp. (PMO 234.233H) scales from Kroksund (sample PMO 234.233). (N) Thelodus cf. laevis (NRM-PZ C6078). (O) L. grossi (NRM-PZ C6079) (P) L. einari (NRM-PZ C6080). (Q-R) P. martinssoni (NRM-PZ C6081-6082). (S-U) cf. Tyriaspis whitei (NRM-PZ C6083-6085) from sample NRM-PZ C6062. All specimens are in external view, except E and Q (lateral view), with anterior toward the left. Scale bar represents $0.1 \mathrm{~mm}$. 
Sample PMO 231.150 was taken at Sundvollen, $0.5 \mathrm{~m}$ below the layer with articulated fish remains described above, and is labelled as deriving from "Etage 9-10". This sample contained two anaspid fragments, one identified as $R$. parvula (Fig. 5A) while the other (Fig. $5 \mathrm{~B})$ is reminiscent of the sculpture in Pt. nitida, but considering its fragmentary state it could possibly derive from Pharyngolepis. Sixteen poorly preserved thelodont scales are also present in the sample, the majority (12) probably deriving from a Thelodus sp. (Fig. 5C), but one P. martinssoni (Fig. 5D) and three possible loganelliid scales (Fig. 5E) are also present.

A sample from Kroksund (PMO 234.233), which is geographically in between the Rudstangen and Nes localities mentioned above (also see Fig. 1B), contained a total of 48 thelodont scales; 22 are identifiable as $L$. grossi (Fig. 5F-I), five as L. einari (Fig. 5J, K), three as $P$. martinssoni (Fig. 5L) and 12 as T. cf. laevis (Fig. 5M). This sample was mentioned, but not figured, in the $\mathrm{PhD}$-thesis of Turner (1984), where it was described as coming from a marine limestone bed $12 \mathrm{~m}$ below the $9 \mathrm{~g}$ fish bed.

The NRM-PZ C6062 sample is described as coming from above the fish-bearing strata, despite being labelled "Ringerike 9g". The approximately 208 fragmentary and isolated vertebrate remains found in this sample support a close association with the Rudstangen Fauna. The majority is represented by thelodont scales; 47 are referred to T. cf. laevis (Fig. 5N), 10 to L. grossi (Fig. 5O), 47 to L. einari (Fig. 5P) and 16 to P. martinssoni (Fig. 5Q) including special scales (Fig. 5R). There are also a few osteostracan fragments (Fig. 5S-U) with an ornamentation similar to the fragment found in sample NRM-PZ C6061, that are subsequently referred to as cf. Tyr. whitei as well. One of these fragments (Fig. 5U) has considerably larger tubercles, but has the upturned anterior part on the ridges similar to the smaller tubercles.

\section{Ludlow}

Sundvollen Fm. calcarenite assemblages (Fig. 2: number 14)

The remainder of the disarticulated vertebrate material from the Ringerike Group described here, as well as in Turner \& Turner (1974) and Davies et al. (2005a), come from several calcarenite horizons within the Sundvollen Fm. Given the nature of these deposits, the scales are generally slightly worn and less well preserved compared with the underlying formation, which in some cases makes identification more difficult. The faunal composition of the samples presented in Turner \& Turner (1974) is of a similar composition to that from the underlying Ranberget Mbr.: T. laevis occurs at all levels, L. grossi and/or L. einari occur in all but the stratigraphically highest sample, and P. martinssoni was only described with certainty from three levels. As Phl. elegans is now considered to be absent from the Ranberget Mbr. (see above), the presence of this taxon in the lowest calcarenite level is uncertain and none of the scales from this level were figured in Turner \& Turner (1974).

Part of sample 295 in Turner \& Turner (1974) from the lowest calcarenite level was available for study by the current authors and contained a total of 85 thelodont scales. The majority of the scales, however, are worn, which hampers identification, but it is possible to confirm the presence of 27 L. grossi (Fig. 6A-E), 10 L. einari (Fig. 6F-I) and 12 Thelodus sp. (Fig. 6J, K).

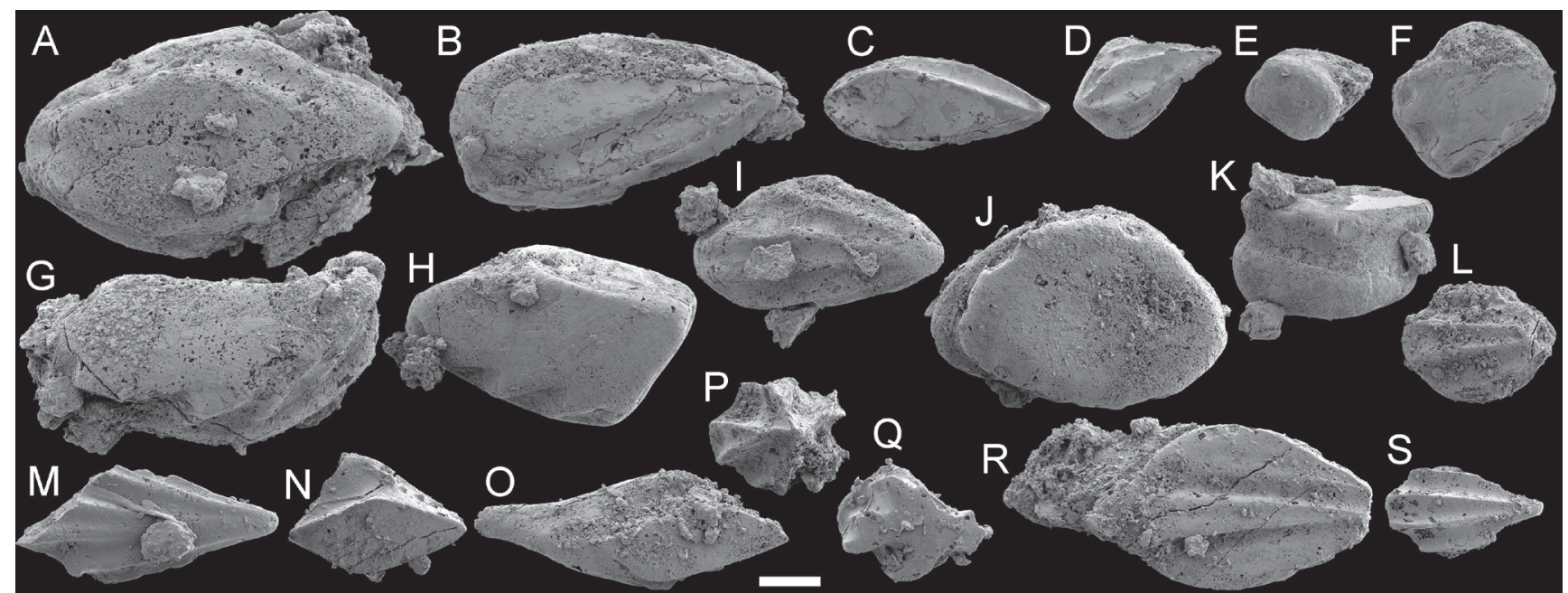

Figure 6. (A-E) Loganellia grossi (LEIUG 123362-123366). (F-I) Loganellia einari (LEIUG 123367-123370). (J-K) Thelodus sp. (LEIUG 123371-123372) from sample 295 (LEIUG 123381). (L-M) L. einari anterior (L; LEIUG 123373) and trunk (M; LEIUG 123374) scales. (N-O) Paralogania martinssoni (LEIUG 123375-123378). (R-S) Thelodus laevis, trunk (R; LEIUG 123379), and posterior (S; LEIUG 123380) scales from sample LEIUG 123383. All scales are in external view, except E (basal view) and $K$ (lateral view), with anterior toward the left. Scale bar represents $0.1 \mathrm{~mm}$. 
Sample LEIUG 123383 comes from a higher calcarenite level and contained a total of 37 thelodont scales, three of which are identified as L. einari, (Fig. 6L, M), four as P. martinssoni (Fig. $6 \mathrm{~N}-\mathrm{Q}$ ) and 12 as T. laevis, (Fig. $6 \mathrm{R}, \mathrm{S})$. The remaining scales are too worn to be readily identified, but are all referable to either shieliid or loganelliid taxa.

The exhaustive review of scale-based taxonomy of thelodonts presented by Märss et al. (2007) enables (and necessitates) a revision of the vertebrate remains from the calcarenites of Sundvollen Fm. described in Davies et al. (2005a). The specimen identified as Goniporus alatus (Davies et al., 2005a: fig. 3A) lacks the typical features for this taxon, namely a flat medial crown with two pairs of lateral extensions (lateral-most wing like) separated from the medial part by slits (see Märss et al., 2007: fig. 91A). It is similar to another scale figured by Davies et al. (2005a: fig. 3C), and collectively they resemble loganelliid scales, although a more specific identification is difficult based on the available image. The second scale (Davies et al., 2005a: fig. 3B) was described as Loganellia sp. and is similar to the scale figured in Davies et al. (2005a: fig. 3E), which was described as Loganellia tuvaensis together with a second scale (Davies et al., 2005a: fig. $3 F)$. However, these scales lack the distinct neck ridge commonly seen in L. tuvaensis (compare KaratajūtèTalimaa, 1978: pl. 18), and if the presented scales do have the anterior notch typical for this taxon (Märss et al., 2007), they are more reminiscent of the L. grossi scales in Turner \& Turner (1974: fig. 4b, d). Another of the figured scales (Davies et al., 2005a: fig. $3 \mathrm{~K}$ ) is also more similar to scales of L. grossi (Märss, 1996: pl. 2, fig. 8, 11) with its pointed, slanting crown hosting two lateral ridges. This was initially described as Thelodus sculptilis by Davies et al. (2005a), but it does not have the flat crowns dissected by deep grooves typical for this taxon (Märss et al., 2007: fig. 102). The scale identified as Loganellia scotica (Davies et al., 2005a: fig. 3D) is, in our opinion, more similar to L. einari with its several crown ridges above two lateral rims that converge toward the posterior point (compare Märss, 1996: pl. 1). In fact, it is almost identical to one of the L. einari scales presented in Turner \& Turner (1974: fig. 4f). This is also true for the two scales figured as Thelodus traquairi (Davies et al., 2005a: fig. 3M, N) that do not display the steeply inclined crown with a knee-like bend typical for the T. traquairi scale type (Gross, 1967). Furthermore, the anteriorly broken scale described as the late Ludlow index taxon T. sculptilis (Davies et al., 2005a: fig. 3L) also looks more like a broken L. einari scale. The state of preservation for one of the T.parvidens scales (Davies et al., 2005a: fig. 3I) makes identification difficult, but two ridges on the crown with a longitudinal medial groove follow the same picture as some other scales of simple L. einari. The scale in Davies et al. (2005a: fig. 3J) has typical loganelliid base and therefore cannot be identified as Thelodus. Interestingly, Davies et al. (2005a) described acanthodian (Gnathostomata) scales from their calcarenite samples, although referring to them as "agnathan fishes". They identified these scales as Radioporacanthodes biblicus (Davies et al., 2005a: fig. $3 \mathrm{G}, \mathrm{H})$. Acanthodian scales start to occur more readily in the fossil record of mid-Ludlow strata of the Baltic Basin (e.g., Märss, 1986; Fredholm, 1988a), although poracanthodid scales are generally found in upper Ludlow strata onward. One of the acanthodian scales (Davies et al., 2005a: fig. 3G) is reminiscent of Nostolepis with its slanting crown hosting ridges that converge toward a single posterior point (e.g., Gross, 1947). The overall morphology of the slightly abraded, second figured scale (Davies et al., 2005a: fig. 3H) suggests an ischnacanthid or poracanthodid affinity. However, it is not possible to make any further comments about these scales solely based on the figure shown in Davies et al. (2005a).

\section{Systematic palaeontology}

$$
\text { Subclass THELODONTI Jaekel, } 1911
$$

\section{Order LOGANELLIIFORMES Turner, 1991}

\section{Family LOGANELLIIDAE Märss et al., 2002}

\author{
Genus Loganellia Fredholm, 1990 \\ Loganellia grossi Fredholm, 1990 \\ Figs. 3K-O, U, 4S, 5F-I, O, 6A-E.
}

Synonyms: See Märss et al. (2007).

Material: Two scales in Gjettum Station 7 (PMO 234.231), 11 in Gjettum Station 8 (PMO 234.231), one in Øverland 1 (PMO 234.232), one L. cf. grossi in NRM-PZ C6063, 21 in Kroksund (PMO 234.233), 10 in NRM-PZ C6062, 27 in LEIUG 123381 and three in sample LEIUG 123383.

Description: The scales treated here generally conform with the updated diagnosis presented in Märss (1996). The trunk scales are tear-drop shaped with a smooth crown surface hosting an anterior notch as well as two down-stepped lateral rims. The dimensions of the base generally conform to the crown, but can in some cases (especially in the Kroksund sample) be enlarged and deep with a minute pulp opening at the posterior end (Fig. 6E). A few scales show morphologies more typical of anterior and head scales (Fig. 3M), with a smooth and flat crown surface but strongly crenulated rims. These are, however, difficult to tell apart between different loganelliid taxa, making their designation less certain. 
Loganellia einari Märss, 1996

Figs. 3Q-T, 4G-H, M, T, 5J-K, P, 6F-I, L-M.

Synonyms: See Märss et al. (2007).

Material: 15 scales in Øverland 1 (PMO 234.232), three in LEIUG 123382, 18 in NRM-PZ C6061, 8 in NRM-PZ C6063, five in Kroksund (PMO 234.233), 47 in NRM-PZ C6062 and 10 in LEIUG 123381.

Description: The L. einari scales described here range from head scales (Fig. 3P, but see previous comment) and more anterior scales (e.g., Figs. 3Q \& 6G), to typical trunk scales (e.g., Figs. 3S \& 5P) and elongated posterior and pinnal scales (Fig. 4M, T). The trunk and more posterior scales have gently inclined crowns hosting several narrow ridges that converge toward the single, posteriorly overhanging point. The base is generally shallow and of similar dimensions as the anterior crown, and hosts a posteriorly placed pulp opening. The scales are sometimes trumpet-shaped with very ribbed crowns (e.g., Fig. 5P).

\section{Loganellia cf. aldridgei Turner, 2000}

Fig. 3A-F.

Referred: Loganellia? sp.

(Turner, 1984; Appendix Fig. 1G-I)

Synonyms: See Märss et al. (2007).

Material: 29 scales in Bjellum 1 (PMO 234.229).

Description: The scales are of two different shapes: a few are shorter, with more prominent crown ridges (Fig. 3A-C), whereas most have slim, elongate pointed crowns and anterior basal spurs (Fig. 3D-F). In young scales, a basal pulp opening can be seen housed at the distal end of a dish-like depression. The majority are typical, elongated trunk scales with a median trough and two main medial ridges that meet before the single posterior tip. The crown is mostly horizontal with a slight downward bend anteriorly, and can sometimes host one or more ridges on the lateral sides. The base is usually wider than the crown and commonly hosts an anterior process, as well as a posteriorly placed pulp opening in an open or more closed groove, depending on the age of the scale.

Remarks: The main difference compared with another Llandovery loganelliid, L. scotica, is the smaller size and more elongated and narrow crown morphology. Loganellia aldridgei was also described as having a histology more similar to Loganellia sibirica than $L$. scotica (Turner, 2000), but no histological details of the small black scales from the sample treated here were discernible when submerged in aniseed oil and attempts at thin-sectioning were unsuccessful.
?Loganellia sp. indet.

Fig. 7 and Electronic Supplement 1: Fig. 1

Material: Around 50 articulated specimens from the Rudstangen fish locality at Ringerike, Norway.

Description: The thelodonts from the Rudstangen locality are generally rather poorly preserved. Only the five best-preserved specimens have been chosen for description in this study, but they only have limited areas that reveal details about the body and scale morphology. Four of the five specimens presented here are represented by part and counterpart, and are generally quite variable in what part of the body they come from and how well they are preserved.

In terms of body outline, PMO 2015a-b (part and counterpart) is the most complete with the head, trunk and most of the tail preserved (Fig. 7A, B). In general form, this specimen resembles loganelliid thelodonts known from elsewhere, such as L. scotica from the lower Silurian of Scotland (e.g., Märss et al., 2007); however, there is no clear sign of fins or a lobate tail. The specimen itself is about $105 \mathrm{~mm}$ in length, which could be extrapolated to a complete body length of about 110-120 $\mathrm{mm}$. In its anterior part, there are patches that reveal a typical round or oval loganelliid head scale morphology with marginal notches (Fig. 7C). Elongated and wedgeshaped trunk scales with lateral ridges are also preserved in patches (Fig 7D, E), but the poor preservation does not allow a more precise description. Scales toward the leading edge of the caudal fin tend to be even more elongated (Fig. 7F).

Specimen PMO 230.338a-b is also represented by part and counterpart (Electronic Supplement 1: Fig. 1A, B), which possibly preserves portions of the trunk judging from the few informative patches of elongated scales.

The third specimen, represented by part and counterpart (PMO E0844, Electronic Supplement 1: Fig. 1E) and (PMO E0851, Fig. 7G), preserves only a narrow patch

Figure 7. Stereomicroscope photographs of three articulated ?Loganellia sp. indet specimens under alcohol. All specimens come from the Rudstangen fish locality. (A-B) Part and counterpart (PMO 2015a-b) of almost complete body with head, trunk and tail. (C) Close up of the head region of specimen PMO 2015a (c on Fig. 7A). (D) Close up of the trunk region of specimen PMO 2015a (d on Fig. 7A). (E) Close up of the trunk region of specimen PMO 2015a (e on Fig. 7A). (F) Close up of the tail region of specimen PMO 2015a ( $f$ on Fig. 7A). (G) Specimen PMO E0851 with part of head and trunk. $(H)$ Specimen PMO E0854 with anterior part of trunk. (I) Close up of the head region of specimen PMO E0851 ( $i$ on Fig. 7G). (J) Close up of the anterior trunk region of specimen PMO E0854 ( $j$ on Fig. $7 H$ ). (K) Close up of the anterior trunk region of specimen PMO E0854 ( $k$ on Fig. $7 H$ ). Scale bars equal to $2 \mathrm{~cm}$ in $A-B$ and $G-H$ and $2 \mathrm{~mm}$ in $C-F$ and $I-K$. 


of scales. Judging from the grading variety of scale morphologies, this represents both part of the head and trunk (Fig. 7I).

Despite being given different collection numbers, PMO E0841 (Electronic Supplement 1: Fig. 1D) and PMO E0854 (Fig. 7H) are counterparts of each other. They represent a rather broad part of the animal that, together with the elongated and wedge-shaped morphology of some of the scales, indicates a rather anterior portion of the trunk (Fig. 7J, K).

PMO E1142 is a rather large specimen showing what appears to be the posterior part of the head and most of the trunk (Electronic Supplement 1: Fig. 1C). There is a patch of scales expanding laterally at the point where the head and trunk meet, which could be part of one of the paired lateral flaps or fins. However, no scales are preserved well enough to support this conclusion.

Remarks: Judging from the finds of disarticulated $L$. grossi and L. einari scales from localities in this area, it is possible that this set of articulated specimens from Rudstangen may represent any one of these species. This, however, is uncertain and since the preservation of scale morphology in this set is limited we can only leave this question open. However, the complete lack of traces of spines on the crown in any of the broken scales of all the specimens studied, supports a Loganellia affinity, rather than a shieliid one, such as $P$. martinssoni, which is also found as disarticulated scales within this interval.

\section{Order SHIELIIFORMES Märss et al., 2002}

$$
\text { Family SHIELIIDAE Märss et al., } 2002
$$

$$
\begin{gathered}
\text { Genus Paralogania Karatajūtè-Talimaa, } 1997 \\
\text { Paralogania martinssoni Gross, } 1967 \\
\text { Figs. 4D-E, J-L, 5D, L, Q, 6N-Q. }
\end{gathered}
$$

Synonyms: See Märss et al. (2007).

Material: Two scales in LEIUG 123382, 10 in NRM-PZ C6061 (including 2 palmatilobate), one in PMO 230.150, three in Kroksund (PMO 234.233), 16 in NRM-PZ C6062 and four in LEIUG 123383.

Description: The scales of $P$. martinssoni differ from those of loganelliids by having up to four lateral spines on each side of the crown, although only the bases of them are preserved in the scales presented here (Fig. 6N). The crown is flat with a rhomboidal outline and sharp edges to the neck all around. The neck is gently curved in toward the base, which is much wider than the crown, anteriorly displaced, and hosts a broad anterior spur as well as a posteriorly placed pulp opening.
Order THELODONTIFORMES Kiær, 1932

\section{Family COELOLEPIDIDAE Pander, 1856}

\author{
Genus Thelodus Agassiz, 1838 \\ Thelodus laevis Pander, 1856 \\ Figs. 3V-Z, 4R, 5M-N, 6R-S.
}

Synonyms: See Märss et al. (2007).

Material: Five scales in Øverland 1 (PMO 234.232), three in NRM-PZ C6063, 12 T. cf. laevis in Kroksund (PMO 234.233) and 47 T. cf. laevis in NRM-PZ C6062, 12 in LEIUG 123383.

Description: The Øverland 1 sample contained the most varied and diagnostic assemblage of $T$. laevis scales. These include crenulated head scales (Fig. 3V), trunk scales with flat crowns and down-stepped lateral rims (Fig. 3W), trunk scales with tear-drop shaped and ridged crowns (Fig. 3X), as well as more elongated and ridged posterior (Fig. 3Y) and pinnal scales (Fig. 3Z). A similar range of scale morphologies was found in the sample LEIUG 123383 (Fig. 6R-S). The neck is generally low and the base is commonly moderately deep with a rounded outline and a centrally placed pulp opening. Some of the scales also have bases with an anterior spur (Figs. 3Y \& 6R). An ultrasculpture consisting of fine striations, which is typical for T. laevis (Märss, 2006b), can be seen on the posterior part of the crown surface on one of the figured scales (Fig. $5 \mathrm{~N}$ ).

\section{Thelodus sp. \\ Figs. 3G-J, 4B-C, 5C, 6J-K.}

Material: Four scales in Gjettum Station 1 (PMO 234.230), 9 in LEIUG 123382, 17 in NRM-PZ C6061, 12 in PMO 231.150 and 12 in LEIUG 123381.

Description: The four thelodont scales from Gjettum Station 1 show three different morphologies (Fig. 3G-J). Two of the scales have a typical Thelodus morphology, i.e., a flat, triangular crown with a rounded anterior edge that overhangs the base all around. However, the lateral corners in specimen PMO 234.230B are peculiar because each displays a posterior extension that appears to have been broken off (Fig. 3H). The neck is high and curved inwards all around with vertical riblets close to the base on the posterior and lateral sides of the neck. The base is moderately deep anteriorly, but shallowing slightly posteriorly, and has a centrally placed pulp opening. The bicostatiform scale (Fig. 3I) has the two characteristic straight ridges divided by a median trough running all along the antero-posteriorly outstretched crown. The neck is moderately high and incurved all around. The base has similar dimensions as the crown and hosts an outstretched pulp opening. The trilobatiform scale (Fig. $3 J$ ) has a restricted neck and an oval-shaped, flat crown 
hosting two closely set medial ridges divided by a shallow furrow. Two additional, lateral ridges are preserved further back on the crown, but the posterior end has been broken off. Similar to the other scale forms, the neck has a sharp ridge to the base, but the base of the trilobatiform scale is anteriorly displaced and has a small anterior spur.

The remaining scales of the other samples only show general Thelodus-like features (i.e., smooth and flat crowns with oval or tear-drop shaped outlines, incurved necks, rounded bases with a central pulp cavity), but it is likely that most of them derive from T. laevis. However, they are treated in an open nomenclature since no diagnostic $T$. laevis scales were recovered from these samples.

Remarks: The general form of the four scales in sample PMO 234.230 described here are similar to those found in the T. parvidens squamation (Märss et al., 2007), with the exception of the lateral extensions on one of the trunk scales (Fig. $3 \mathrm{H}$ ), but similar scales have also been described for T. laevis (Gross, 1967). A single scale from the lower Wenlock of Gotland (Sweden), described as Thelodontida gen. et sp. indet by Ørvig (1979: fig. 73), is strikingly similar in overall shape to the trilobatiform scale from the Gjettum Station 1 sample (Fig. 3J), including the shallow, median furrow which is partly preserved on the surface of the crown (OB, pers. obs. 2018). The scales also show similarities to the lower Wenlock Thelodus inauditus Märss et al. (2006) from the Canadian Arctic, although scales of this taxon lack vertical riblets on the neck. Because of the few specimens, we leave the definite taxonomic identification open for now.

Subclass ANASPIDA Traquair, 1899

Order BIRKENIIDA Berg, 1937

Family RHYNCHOLEPIDIDAE Kiær, 1924

\author{
Genus Rhyncholepis Kiær, 1911 \\ Rhyncholepis parvula Kiær, 1911 \\ Figs. $4 A, Q, 5 A$.
}

Synonyms: See Blom et al. (2002).

Material: Two fragmentary scales in LEIUG 123382, two in NRM-PZ C6063 and one in PMO 231.150.

Description: Most of the surface of these fragmentary specimens is covered by an ornament of rows of flat, triangular spinelets, whereas the anterior surface has more widely spaced and round tubercles. The inter-ridge grooves sometimes have irregularly placed vascular canal openings.
Remarks: The ornamentation is similar to Rhyncholepis butriangula; however, the spines are generally much smaller and therefore the fragments are referred to $R$. parvula.

\section{Family PTERYGOLEPIDIDAE Obruchev, 1964}

\section{Genus Pterygolepis Cossmann, 1920 cf. Pterygolepis nitida Kiær, 1911} Figs. 4I, 5B.

Synonyms: See Blom et al. (2002).

Material: One fragmentary scale in NRM-PZ C6061 and one in PMO 231.150.

Description: The external surface in both specimens is covered by large and smooth, irregularly shaped ridges that are sometimes slightly curved (Fig. 4I) and connected (Fig. 5B). The anterior surface has smaller, rounded tubercles.

Remarks: The ornamentation of these fragments is distinct from the $R$. parvula described before, although the fragmentary state of these anaspid specimens makes a taxonomic designation uncertain, especially when distinguishing them from similarly ornamented anaspids such as Pharyngolepis. However, the ornamentation is especially similar to one of the scales described for Pt. nitida by Blom et al. (2002: fig. 21G).

\section{Subclass OSTEOSTRACI Lankester, 1868}

\author{
Osteostraci gen. et sp. indet.
}

Fig. 4O-P, U.

Material: Three fragments in NRM-PZ C6061 and one in NRM-PZ C6063.

Description: The entire surface of these fragmentary specimens is covered by irregular ridges of different lengths with small ridgelets along their sides. There are smooth areas in between the main ridges that host rather large, irregularly placed canal openings. The base of the elements is generally smooth with a few dispersed and large canal openings.

Remarks: No successful comparison to articulated material from the same area has been made, but the body sculpture in both Hirella and Ateleaspis consists of longitudinal ridges (Heintz, 1969). One of the osteostracan specimens figured by Gross (1968b: fig. 6F) is similar to the ones described here. 


\section{Order THYESTIIDA Berg, 1940}

\section{Family TREMATASPIDOIDAE Afanassieva, 1991}

\author{
Genus Tyriaspis Heintz, 1967 \\ cf. Tyriaspis whitei Heintz, 1967 \\ Figs. $4 \mathrm{~N}, 5 \mathrm{~S}-\mathrm{U}$.
}

Material: Five fragmentary remains in NRM-PZ C6061, three in NRM-PZ C6063, one in NRM-PZ C6064 and three in NRM-PZ C6062.

Description: Most of the fragmentary specimens have closely set, star-shaped tubercles composed of irregularly distributed radial ridges that meet at a more or less centrally positioned peak. One of the fragments (Fig. 5T) has only a single tubercle of a similar shape, but of a considerably larger size. Specimen NRM-PZ C6085 (Fig. $5 \mathrm{U}$ ) hosts an even larger tubercle, as well as a smaller one of similar morphology. The ridge has a number of small ridgelets separated by shallow grooves at its anterior end that become more prominent along the sides. The ridges converge and smooth out toward the single posterior point of the entire tubercle. All of the fragmentary specimens have an anterior hook directed upwards on several of the ridges of their tubercles.

Remarks: The ornamentation of stellate tubercles in all the specimens is comparable to that in articulated specimens of Tyr. whitei (OB \& HB, pers. obs. 2018). The ornamentation of small, rounded tubercles is also reminiscent of that found in the coeval Saaremaaspis mickwitzi Rohon 1892, although the tubercles in $S$. mickwitzi have less prominent ridges that lack the distal hooks. More specimens are needed before a definite assignment is possible.

\section{Discussion}

The exceptionally well-preserved Silurian vertebrates of the Rudstangen Fauna and associated localities in the Oslo Region of Norway have been important for our understanding of early vertebrate morphology and evolution. However, the studies of disarticulated vertebrate microremains, and subsequently the distribution of vertebrates, in this area has remained relatively poorly understood and largely restricted to the pioneering studies of Gross (1968), Turner \& Turner (1974) and Turner (1984). In addition, the articulated thelodont specimens found by J. Kiær have been neglected for over 100 years.

The Silurian stratigraphy of the Oslo Region has remained problematic largely because of its complex sedimentary and tectonic history (see Worsley et al.,
1983 for an exhaustive review), but advances in our understanding of the regional geology have been made during the last two decades (e.g., Davies, 2003; Davies et al., 2005a, b, c, 2006). The early studies of the articulated Rudstangen Fauna proposed a Ludlow age for the basal Ringerike Group based on similarities of the fauna to those of Britain, Estonia and southern Sweden (Heintz, 1939), whereas an end-Wenlock age was suggested in later works (Blom et al., 2002). Articulated specimens of osteostracans from toward the top of the Ringerike Group from the Holmestrand Fm. (Turner, 1974b) put an upper age limit for the top of the Ringerike Group to early Pridoli (Heintz, 1974; Calner et al., 2013). Early attempts at using vertebrate microremains as an additional biostratigraphical tool in the Oslo Region (Worsley et al., 1983) indicated that the interval containing the Rudstangen Fauna (i.e., the transition between the Steinsfjorden Fm. and the Ringerike Group in the Ringerike area) approximated to the WenlockLudlow boundary (Turner \& Turner, 1974). However, these assessments were heavily criticised by Davies et al. (2005a), who also questioned in general the validity of the global Silurian vertebrate biozonal scheme of Märss et al. (1995); updated in Märss \& Männik (2013). Davies et al. (2005a) argued that reworking due to transport of calcarenite material restricts any age determination on the basis of vertebrate remains. They further commented that the data and material presented by Vergoossen (2003), together with unresolved inaccuracies in the vertebrate biozonation, suggest that the microvertebrate remains found in the Ringerike Group are biased by facies rather than being a reliable biostratigraphical tool because they include index taxa that show a wide variety of ages (Davies et al., 2005a).

Nevertheless, the well-studied record of vertebrates from the Silurian of the Baltic Region and elsewhere in Europe have provided a detailed framework for biostratigraphy and correlation (Blieck \& Turner, 2000; Märss \& Männik, 2013). Particularly thelodonts, with the addition of anaspids, osteostracans and acanthodians (e. g., Blom et al., 2002; Valiukevičius, 2005; Märss et al., 2007, 2014; Turner et al., 2017), are considered a significant complement to other well-established biozonations. We agree with Davies et al. (2005a) that facies dependence is an important subject for further exploration in the vertebrate record (Bremer \& Blom, 2015; Bremer et al., 2017), which needs to be well understood for a successful application of the vertebrate biozonation scheme. However, we also think that their conclusions were premature in the light of the material presented and the identifications they made (Davies et al., 2005a). This is also true for remains discussed in Vergoossen (2002, 2003), which most likely is a mislabelled sample coming from the upper Silurian of southern Sweden, and should therefore be excluded in any future considerations. With our new data, together with the reassessment of the figured microremains in Davies et al. (2005a), we argue that their conclusion that the Sundvollen Fm. assemblage 
shows a wide variety of ages must be challenged. The vertebrate material of the calcarenites that they studied has most likely been redeposited considering the highly abraded nature of the material figured by Davies et al. (2005a: fig. 3), but the included taxa agree well with a general Ludlow age. Considering the diachronous nature of the transition of the Steinsfjorden Fm. to the Ringerike Group (Worsley et al., 1983; Davies, 2003), the continued marine depositional setting to the south could then have acted as the source for the Sundvollen Fm. calcarenites, but clearly there are better preserved vertebrate remains in other samples that indicate that the fish were living in contemporary environmental settings.

Considering the proposed ages of the stratigraphical units of the Oslo Region based on other studies (summarised in Fig. 2), the vertebrate assemblages presented here generally agree with the proposed ages of the vertebrate biozones (Märss et al., 1995; Märss \& Männik, 2013) presented in the right column of Figure 2. Scales that are similar to the Llandovery taxon $L$. aldridgei are found in the PMOGHA2 and Bjellum 1 (PMO 234.229) samples (numbers 1 and 2 in Fig. 2). The Gjettum Station 7 and 8 samples (PMO 234. 231; numbers 4 and 5 in Fig. 2) only contained L. grossi, while the Øverland 1 sample (PMO 234. 232; number 6 in Fig. 2) contained L. grossi, L. einari and T. laevis. This would place these samples somewhere in the transition between the Loganellia grossi and Loganellia einari Vertebrate Zones, spanning mid- to late Wenlock ages (Märss \& Männik, 2013). The following vertebrate biozone is defined by the first appearance of the index taxon P. martinssoni, which was reported from the top of the Steinsfjorden Fm. in the Ringerike area by Turner \& Turner (1974). This taxon is also present in the samples labelled $9 \mathrm{~g}$ presented in this study, namely samples LEIUG 123382, NRM-PZ C6061, NRM-PZ C6063 and NRM-PZ C6064 (7-10 in Fig. 2). This agrees well with the late Wenlock (Homerian) age of the P. martinssoni VZ (Märss \& Männik, 2013). However, several of these samples also contained $L$. grossi and $L$. einari, giving a much longer overlap of these three taxa compared to elsewhere (Märss \& Männik, 2013). The same is true for the samples from the lowermost Sundvollen Fm. (11-13 in Fig. 2). Because P. martinssoni VZ stretches into the lower Ludlow, a more precise placement than somewhere close to the Wenlock-Ludlow transition is not possible. The taxon range of P. martinssoni stretches through the following Phlebolepis ornata and Phlebolepis elegans vertebrate zones, and occurs in several of the less stratigraphically controlled calcarenite samples from the Ringerike Group. On Gotland, the Phl. ornata level (Fredholm, 1988b) and the following Phl. elegans VZ (Märss \& Männik, 2013), occurs somewhere in the Gorstian (Jeppsson et al., 2006). This could put an upper limit for the Sundvollen Fm., or at least some of the calcarenite levels, considering that the presence of Phlebolepis has not been confirmed in the Sundvollen Fm. calcarenites. On the other hand, long time intervals may be represented between these levels, especially when scales presented by Davies et al. (2005a) as acanthodians, that are more typical for the Ludfordian, are taken into account.

\section{Conclusions}

Several works on the geology and stratigraphy of the Oslo Region during the last decades have greatly improved our understanding of its complex depositional history, as well as the interrelationships of the strata. This provides a new framework for the placement of previously reported and undescribed samples containing vertebrates in the region.

Articulated thelodonts from the famous Rudstangen locality are described here for the first time. The five best-preserved specimens out of a larger collection housed at PMO were selected for investigation. It is possible to see some of the differing scale morphologies on the specimens, such as rounded head scales with lateral notches and more elongated scales on the trunk and leading edges of the fins. The specimens appear to be monogeneric, but because of the generally poor state of scale preservation, it is only possible to designate them as ?Loganellia sp. indet.

Previous reports of vertebrate microremains from the Oslo Region are reviewed and revised in this study, and previously undescribed or unpublished material from museum collections are presented. The disarticulated material displays a relatively large taxonomic diversity. Thelodonts include L. cf. aldridgei, L. grossi, L. einari, $P$. martinssoni, T. laevis and Thelodus sp. Anaspid remains are identified as $R$. parvula and some as deriving from Pt. nitida or possibly Pharyngolepis, both of which have previously been described from this area (Blom et al., 2002). Osteostracan remains are putatively assigned to Tyr. whitei, along with fragments of two morphologies that are left in open nomenclature.

The distribution of the thelodont faunas, when placed within the stratigraphical framework presented for the Oslo Region, compares well to the established vertebrate biozonation updated in Märss \& Männik (2013). This is in contrast to the conclusions of Davies et al. (2005a). However, we agree that a detailed biostratigraphy of the Sundvollen Fm. is hampered by the allochthonous nature of the calcarenites containing the vertebrate remains. It has to be emphasised that the sample mentioned by Vergoossen (2002), which caused the largest temporal discrepancies according to Davies et al. (2005a), most likely was mislabelled and instead derives from the upper Silurian of Skåne, southern Sweden. This sample should therefore not be considered in future investigations of the area. Overall, the microremains associated with the 
Rudstangen Fauna agree well with end-Wenlock and early Ludlow faunas of Gotland and Estonia, supporting the previous notion that the lower part of the Ringerike Group in this area approximates to the Wenlock/Ludlow transition.

The Silurian vertebrates of the Oslo Region are also interesting from a palaeobiogeographical point of view. The oldest remains, described here as L. cf. aldridgei, are closely associated with Llandovery faunas of Britain, while younger loganelliids show a closer comparison to Baltic and northern Russian forms (Märss \& Männik, 2013). Anaspids are also similar to forms described from the Baltic Basin, whereas osteostracans are not. The four thelodont scales from Gjettum Station 1 (Telychian) confirm the presence of thelodontids already in the Llandovery. Furthermore, these scales show morphologies that are close to the typical late Silurian $T$. parvidens with the exception of lateral extensions on the crown, although similar variants also appear in scale-sets of older taxa such as T. laevis.

Additional sampling for microremains of vertebrates within the Oslo Region would prove fruitful and will potentially provide better control for the biostratigraphy of the area, as well as giving further insights into the distribution patterns of early Silurian vertebrates of the northern hemisphere Palaeozoic terranes.

Acknowledgements. The authors are thankful to the late Professor Dick Aldridge for sharing his material from the Oslo Region. We also thank Dr Alex Ritchie for sharing his data for this study, as well as Hans Arne Nakrem and Thomas Mörs for giving us access to the collections of the PMO and NRM PZ, respectively. We also want to thank Michael Streng (Uppsala University) for his help with the SEM and the reviewers for their helpful comments that improved this work. ST thanks the Board and Directorate of the Queensland Museum for their ongoing support.

\section{References}

Afanassieva, O.B. 1991: Tsephalaspidi Sovetskogo Soyuza (Agnatha) [Cephalaspids of the Soviet Union]. Trudy Paleontologicheskogo Instituta, Akademiya Nauk SSSR 248, 1-144.

Agassiz, L. 1838: On the Fishes of the Ludlow Rocks, or Upper Beds of the Silurian System. In Murchisson, R.I. (ed.): Report of the British Association for the Advancement of Science, 7th Transactions, Liverpool, pp. 91

Aldridge, R.J. \& Mohamed, I. 1982: Conodont biostratigraphy of the early Silurian of the Oslo Region. IUGS Subcommission on Silurian Stratigraphy, Field Meeting, Oslo Region, Paleontological Contributions from the University of Oslo 278, 109-120.

Baarli, B.G. 1990: Peripheral bulge of a foreland basin in the Oslo Region during the early Silurian. Palaeogeography, Palaeoclimatology, Palaeoecology 78, 149-161. https://doi.org/10.1016/0031-0182(90)90209-P.

Baarli, B.G. \& Johnson, M.E. 1988: Biostratigraphy of key brachiopod lineages from the Llandovery Series (Lower Silurian) of the Oslo Region. Norwegian Journal of Geology 68, 259-274.
Baarli, B.G., Keilen, H.B. \& Johnson, M.E. 1999: Silurian communities of the Oslo Region, Norway. In Boucot, A.J. \& Lawson, J.D. (eds.): Paleocommunities: A Case Study from the Silurian and Lower Devonian, Cambridge University Press, pp. 327-349.

Bassett, M.G. \& Rickards, R.B. 1971: Notes on Silurian stratigraphy and correlation in the Oslo district. Norwegian Journal of Geology 51, 247-260.

Berg, L.S. 1937: A classification of fish-like vertebrates. Bulletin de l'Académie des Sciences de l'URSS 4, 1277-1280.

Berg, L.S. 1940: Classification of Fishes, both Recent and Fossil. Trudy Zoologicheskogo Instituta, Akademiia Nauk SSSR 5, 346-517.

Blieck, A. \& Turner, S. 2000: Palaeozoic vertebrate biochronology and global marine/non-marine correlation. Courier Forschungsinstitut Senckenberg 223, 1-575.

Blom, H. 2003: Loganellia (Thelodonti, Agnatha) from the Lower Silurian of North Greenland. Acta Geologica Polonica 49, 97-104.

Blom, H., Märss, T. \& Miller, C.G. 2002: Silurian and earliest Devonian birkeniid anaspids from the Northern Hemisphere. Earth and Environmental Science Transactions of the Royal Society of Edinburgh 92, 263-323. https://doi.org/10.1017/S0263593300000250.

Bremer, O. \& Blom, H. 2015: An updated stratigraphic and environmental framework for the distribution of Silurian vertebrates on Gotland. Estonian Journal of Earth Sciences 64, 13-18. https://doi.org/10.3176/earth.2015.03.

Bremer, O., Niedźwiedzki, G., Blom, H., Dec, M. \& Kozłowski, W. 2017: Vertebrate microremains from the upper Silurian Winnica Formation of the Holy Cross Mountains, Poland. Geological Magazine 155, 1523-1541. https://doi.org/10.1017/S0016756817000681.

Calner, M., Ahlberg, P., Lehnert, O. \& Erlström, M. 2013: The Lower Palaeozoic of southern Sweden and the Oslo Region, Norway. Field Guide for the 3rd Annual Meeting of the IGCP Project 591. SGU Rapporter och meddelanden 133, 1-96.

Cossmann, M. 1920: Retification de nomenclature. Revue critique de Paléozoologie et de Paléophytologie 2, 1-83.

Davies, N.S. 2003: The Ringerike Group (Late Silurian, Oslo Region): palaeoenvironmental analysis of an Old Red Sandstone sequence in the foreland basin of the Norwegian Caledonides. Unpublished $\mathrm{PhD}$ thesis, Birmingham University, $271 \mathrm{pp}$.

Davies, N.S., Turner, P. \& Sansom, I.J. 2005a: A revised stratigraphy for the Ringerike Group (Upper Silurian, Oslo Region). Norwegian Journal of Geology 85, 193-202.

Davies, N.S., Turner, P. \& Sansom, I.J. 2005b: Caledonide influences on the Old Red Sandstone fluvial systems of the Oslo Region, Norway. Geological Journal 40, 83-101. https://doi.org/10.1002/gj.988.

Davies, N.S., Turner, P. \& Sansom, I.J. 2005c: Soft-sediment deformation structures in the Late Silurian Stubdal Formation: the result of seismic triggering. Norwegian Journal of Geology 85, 233-244.

Davies, N.S., Sansom, I.J. \& Turner, P. 2006: Trace fossils and paleoenvironments of a late Silurian marginal-marine/alluvial system: the Ringerike Group (lower Old Red Sandstone), Oslo region, Norway. Palaios 21, 46-62. https://doi.org/10.2110/palo.2003.p03-08.

Ferrón, H.G., Martínez冈Pérez, C., Turner, S., Manzanares, E. \& Botella, H. 2018: Patterns of ecological diversification in thelodonts. Palaeontology 61,303-315. https://doi.org/10.1111/pala.12347.

Fredholm, D. 1988a: Vertebrates in the Ludlovian Hemse Beds of Gotland, Sweden. Geologiska Föreningen i Stockholm Förhandlingar 110,157-179. https://doi.org/10.1080/11035898809452655.

Fredholm, D. 1988b: Vertebrate biostratigraphy of the Ludlovian Hemse Beds of Gotland, Sweden. Geologiska Föreningen i Stockholm Förhandlingar 110, 237-253. https://doi.org/10.1080/11035898809455448.

Fredholm, D. 1990: Agnathan vertebrates in the lower Silurian of Gotland, Sweden. Geologiska Föreningen i Stockholm Förhandlingar 112, 61-80. https://doi.org/10.1080/11035899009453162. 
Gross, W. 1947: Die Agnathen und Acanthodier des obersilurischen Beyrichienkalks. Palaeontographica Abteilung A, 91-158.

Gross, W. 1967: Über Thelodontier-Schuppen. Palaeontographica Abteilung A, 1-67.

Gross, W. 1968: Die Agnathen-fauna der silurischen Halla-schichten Gotlands. Geologiska Föreningen i Stockholm Förhandlingar 90, 369-400. https://doi.org/10.1080/11035896809448410.

Hairapetian, V., Roelofs, B.P.A., Trinajstic, K.M. \& Turner, S. 2016: Famennian survivor turiniid thelodonts of North and East Gondwana. Geological Society, London, Special Publications 423, 273-289. https://doi.org/10.1144/SP423.3.

Heintz, A. 1939: Cephalaspida from Downtonian of Norway. Skrifter utgitt av Det Norske Videnskaps-Akademi i Oslo, I. MatematiskNaturvitenskapelig Klasse Ny Serie 5, 119 pp.

Heintz, A. 1967: A new tremataspidid from Ringerike, South Norway. Zoological Journal of the Linnean Society 47, 55-68. https://doi.org/10.1111/j.1096-3642.1967.tb01395.x.

Heintz, A. 1969: New Agnaths from Ringerike Sandstone. Skrifter utgitt av Det Norske Videnskaps-Akademi i Oslo, I. MatematiskNaturvitenskapelig Klasse Ny Serie 26, 299 pp.

Heintz, A. 1974: Additional remarks about Hemicyclaspis from Jeløya, southern Norway. Norwegian Journal of Geology 54, 375-384.

Hetherington, C.J., Nakrem, H.A. \& Potel, S. 2011: Note on the composition and mineralogy of Wenlock Silurian bentonites from the Ringerike District: Implications for local and regional stratigraphic correlation and sedimentary environments. Norwegian Journal of Geology 91, 181-192.

Jaekel, O. 1911: Die Wirbeltiere; eine Übersicht über die fossilen und lebenden Formen. Gebrüder Borntraeger, Berlin, 252 pp. https://doi.org/10.5962/bhl.title.119340.

Jarochowska, E. \& Munnecke, A. 2015: Silurian carbonate highenergy deposits of potential tsunami origin: Distinguishing lateral redeposition and time averaging using carbon isotope chemostratigraphy. Sedimentary Geology 315, 14-28.

https://doi.org/10.1016/j.sedgeo.2014.10.012.

Jarochowska, E., Bremer, O., Heidlas, D., Pröpster, S., Vandenbroucke, T.R.A. \& Munnecke, A. 2016: End-Wenlock terminal Mulde carbon isotope excursion in Gotland, Sweden: Integration of stratigraphy and taphonomy for correlations across restricted facies and specialized faunas. Palaeogeography, Palaeoclimatology, Palaeoecology 457, 304-322.

https://doi.org/10.1016/j.palaeo.2016.06.031.

Jeppsson, L., Eriksson, M.E. \& Calner, M. 2006: A latest Llandovery to latest Ludlow high-resolution biostratigraphy based on the Silurian of Gotland-a summary. Geologiska Föreningen i Stockholm Förhandlingar 128, 109-114.

https://doi.org/10.1080/11035890601282109.

Karatajūtè-Talimaa, V. 1978: Silurian and Devonian thelodonts of the USSR and Spitsbergen. Mokslas Publishers Vilnius, Vilnius, 334 pp.

Karatajūtè-Talimaa, V. 1997: Taxonomy of loganiid thelodonts. Modern Geology 21,1-15. https://doi.org/10.5194/fr-1-21-1998.

Kiær, J. 1908: Das Obersilur im Kristianiagebiete. Skrifter utgitt av Det Norske Videnskaps-Akademi i Oslo, I. MatematiskNaturvitenskapelig Klasse II, 596 pp.

Kiær, J. 1911: A new Downtonian fauna in the sandstone series of the Kristiania area. A preliminary report. Skrifter utgitt av Det Norske Videnskaps-Akademi i Oslo, I. Matematisk-Naturvitenskapelig Klasse 7, 22 pp.

Kiær, J. 1924: The Downtonian Fauna of Norway, I Anaspida with a Geological Introduction. Skrifter utgitt av Det Norske VidenskapsAkademi i Oslo, I. Matematisk-Naturvitenskapelig Klasse 6, 139 pp.

Kiær, J. 1931: Hemicyclaspis murchisoni-Faunaen i den Downtoniske Sandsten på Jeløen i Oslo Fjorden. Norwegian Journal of Geology $12,419-433$.

Kiær, J. 1932: New coelolepids from the Upper Silurian on Oesel (Estonia). Publications of the Geological Institution of Tartu University 27, 1-8.
Kjerulf, T. \& Dahll, T. 1857: Über die Geologie des südlichen Norwegens. Nyt Magazin for Naturvidenskaberne 9, 193-306.

Lankester, E.R. 1868: A Monograph of the Fishes of the Old Red Sandstone of Britain. Part I. The Cephalaspidae. Monograph of the Palaeontographical Society, London, $62 \mathrm{pp}$.

Long, J.A. 1994: Palaeozoic vertebrate biostratigraphy and biogeography. Johns Hopkins University Press, 384 pp.

Märss, T. 1982: Vertebrate zones in the East Baltic Silurian. In Kaljo, D., Raukas, A., Männil, R., Klaamann, E., Miidel, A., Pirrus, E. \& Viiding, H. (eds.): Ecostratigraphy of the East Baltic Silurian, Project "Ecostratigraphy", Academy of Sciences of the Estonian SSR Institute of Geology, Tallinn, Valgus, pp. 97-105.

Märss, T. 1986: Silurian vertebrates of Estonia and west Latvia. Fossilia Baltica 1, 104 pp.

Märss, T. 1990: Vertebrates. In Kaljo, D. \& Nestor, H. (eds.): Field Meeting Estonia 1990: An Excursion Guidebook, Estonian Academy of Sciences, Tallinn, pp. 93-96.

Märss, T. 1996: Loganellia (Thelodonti, Agnatha) from the Jaagarahu Stage, Wenlock, Estonia. Proceedings of the Estonian Academy of Sciences, Geology 45, 189-202.

Märss, T. 2006a: Thelodonts (Agnatha) from the basal beds of the Kuressaare Stage, Ludlow, Upper Silurian of Estonia. Proceedings of the Estonian Academy of Sciences, Geology 55, 43-66.

Märss, T. 2006b: Exoskeletal ultrasculpture of early vertebrates. Journal of Vertebrate Paleontology 26, 235-252. https://doi.org/10.1671/0272-4634(2006)26[235:EUOEV]2.0.CO;2.

Märss, T. \& Karatajūtė-Talimaa, V. 2002: Ordovician and Lower Silurian thelodonts from Severnaya Zemlya Archipelago (Russia). Geodiversitas 24, 381-404.

Märss, T. \& Männik, P. 2013: Revision of Silurian vertebrate biozones and their correlation with the conodont succession. Estonian Journal of Earth Sciences 62, 181-204. https://doi.org/10.3176/earth.2013.15.

Märss, T., Wilson, M.V.H. \& Thorsteinsson, R. 2002: New thelodont (Agnatha) and possible chondrichthyan (Gnathostomata) taxa established in the Silurian and Lower Devonian of the Canadian Arctic Archipelago. Proceedings of the Estonian Academy of Sciences, Geology 51, 88-120.

Märss, T., Wilson, M.V.H. \& Thorsteinsson, R. 2006: Silurian and Lower Devonian thelodonts and putative chondrichthyans from the Canadian Arctic Archipelago. The Palaeontological Association, London, $144 \mathrm{pp}$.

Märss, T., Turner, S. \& Karatajūtè-Talimaa, V. 2007: Agnatha II-Thelodonti. Verlag Dr Friedrich Pfeil, Münich, 143 pp.

Märss, T., Afanassieva, O. \& Blom, H. 2014: Biodiversity of the Silurian osteostracans of the East Baltic. Earth and Environmental Science Transactions of the Royal Society of Edinburgh 105, 73-148. https://doi.org/10.1017/S1755691014000218.

Märss, T., Fredholm, D., Talimaa, V., Turner, S., Jeppsson, L. \& Nowlan, G. 1995: Silurian vertebrate biozonal scheme. Geobios 28, 369-372. https://doi.org/10.1016/S0016-6995(95)80140-5.

Martinsson, A. 1969: Correlation of Silurian ostracode faunas in Norway. Ludlow Research Group Bulletin 16, 27-28.

Obruchev, D.V. 1964: Agnathans and fishes. In Orlov, Y.O. (ed.): Fundamentals of Palaeontology, Moscow: Naukau [in Russian], pp. 522.

Opalinski, P.R. \& Harland, T.L. 1981: The Middle Ordovician of the Oslo Region, Norway, 29. Stratigraphy of the Mjøsa Limestone in the Toten and Nes-Hamar areas. Norwegian Journal of Geology 61, $59-78$.

Ørvig, T. 1979: Agnathan vertebrates. In Jaanusson, V., Laufeld, S. \& Skoglund, R. (eds.): Lower Wenlock faunal and floral dynamics Vattenfallet section, Gotland, Sveriges Geologiska Undersökning: Rapporter och meddelanden, C 762, pp. 249-250.

Pander, C.H. 1856: Monographie der fossilen Fische des silurischen Systems des Russisch-Baltischen Gouvernements. Buchdruckerei der Kaiserlichen Akademie der Wissenschaften, St. Petersburg, 91 pp. 
Plax, D. \& Märss, T. 2011: Thelodonts (Agnatha) from the Lower Silurian (Wenlock) deposits of the northwest of Belarus. Litasfera 34, 69-81.

Ritchie, A. 1964: New light on the morphology of the Norwegian Anaspida. Skrifter utgitt av Det Norske Videnskaps-Akademi i Oslo, I. Matematisk-Naturvitenskapelig Klasse Ny Serie 14, pp. 35

Rohon, J.V. 1892: Die obersilurischen Fische von Oesel. I Teil. Thyestidae und Tremataspidae. Mémoires de L'Académie Impériale des Sciences de St.-Petersbourg 38, 1-88.

Skjeseth, S. 1963: Contributions to the geology of the Mjøsa districts and the classical sparagmite area in southern Norway. Norges Geologiske Undersøkelse 220, 1-126.

Smith, I.C. 1956: A note on the axial skeleton of the anaspid Pharyngolepis sp. Arkiv för Zoologi 9, 573-577. https://doi.org/10.1002/j.1537-2197.1956.tb10536.x.

Smith, I.C. 1957: New restorations of the heads of Pharyngolepis oblongus Kiær and Pharyngolepis kiaeri sp. nov., with a note on their lateral-line systems. Norwegian Journal of Geology 37, 373-402.

Squirrell, H. 1958: New occurrences of fish remains in the Silurian of the Welsh Borderland. Geological Magazine 95, 328-332. https://doi.org/10.1017/S0016756800062877.

Størmer, L. 1954: New discoveries of ostracoderms and eurypterids at Ringerike, near Oslo. Proceedings of the Geological Society of London 1505, 21-22.

Thomsen, E., Jisuo, J. \& Harper, D.A.T. 2006: Early Silurian brachiopods (Rhynchonellata) from the Sælabonn Formation of the Ringerike district, Norway. Bulletin of the Geological Society of Denmark 53, 111-126.

Traquair, R.H. 1899: Report on fossil fishes collected by the Geological Survey of Scotland in the Silurian rocks of the south of Scotland. Transactions of the Royal Society of Edinburgh 39, 827-864. https://doi.org/10.1017/S0080456800035237.

Turner, P. 1974a: Marine calcarenites from the Ringerike Group ('Stage' 10 of southern Norway). Norwegian Journal of Geology 54, 1-13.

Turner, P. 1974b: Lithostratigraphy and facies analysis of the Ringerike Group of the Oslo Region. Norges Geologiske Undersøkelse 314, 101-132.

Turner, S. 1973: Siluro-Devonian thelodonts from the Welsh borderland. Journal of the Geological Society 129, 557-582. https://doi.org/10.1144/gsjgs.129.6.0557.

Turner, S. 1984: Studies on Palaeozoic Thelodonti (Craniata: Agnatha). Unpublished $\mathrm{PhD}$ thesis, University of Newcastle-upon-Tyne, 272 pp.

Turner, S. 1986: Thelodus macintoshi Stetson 1928: The largest known Thelodont (Agnatha: Thelodonti). Breviora 486, 1-18.

Turner, S. 1991: Monophyly and interrelationships of the Thelodonti. In Chang, M.-m., Liu, Y. \& Zhang, G.-R. (eds.): Early vertebrates and related problems of evolutionary biology, Science Press, Beijing, pp. 87-119.

Turner, S. 1997: Sequence of Devonian scale assemblages in East Gondwana. Geological Society of America Special Papers 321, 1-45. https://doi.org/10.1130/0-8137-2321-3.295.

Turner, S. 1999: Early Silurian to Early Devonian thelodont assemblages and their possible ecological significance. In Boucot, A.J. \& Lawson, J.D. (eds.): Paleocommunities: a case study from the Silurian and Lower Devonian, World and Regional Geology, Cambridge University Press, pp. 42-78.

Turner, S. 2000: New Llandovery to early Pridoli microvertebrates including Lower Silurian zone fossil, Loganellia avonia nov. sp., from Britain. Courier-Forschungsinstitut Senckenberg 223, 91-128.

Turner, P. \& Turner, S. 1974: Thelodonts from the upper Silurian of Ringerike, Norway. Norwegian Journal of Geology 54, 183-192.

Turner, S., Burrow, C.J., Williams, R.B. \& Tarrant, P. 2017: Welsh Borderland bouillabaisse: Lower Old Red Sandstone fish microfossils and their significance. Proceedings of the Geologists Association 128, 460-479.

https://doi.org/10.1016/j.pgeola.2017.04.006.
Valiukevičius, J. 1998: Acanthodians and zonal stratigraphy of Lower and Middle Devonian in East Baltic and Byelorussia. Palaeontographica Abteilung A, 1-53.

Valiukevičius, J. 2005: Silurian acanthodian biostratigraphy of Lithuania. Geodiversitas 27,349-380.

Vergoossen, J. 2002: Late Silurian fish microfossils from Ramsåsa, locality H, Scania, south Sweden, with some remarks on the body zonation scheme used in thelodont studies. Scripta Geologica 123, 41-69.

Vergoossen, J. 2003: Fish microfossils from the upper Silurian Öved Sandstone Formation, Skåne, Southern Sweden - A paleontological appraisal of biostratigraphical tools. Unpublished $\mathrm{PhD}$ thesis, Rijksuniversiteit Groningen.

Worsley, D., Aarhus, N., Bassett, M.G., Howe, M.P.A., Mørk, A. \& Olaussen, S. 1983: The Silurian succession of the Oslo region. Norsk Geologiske Undersøkelse 384, 1-57. 


\section{Appendix}
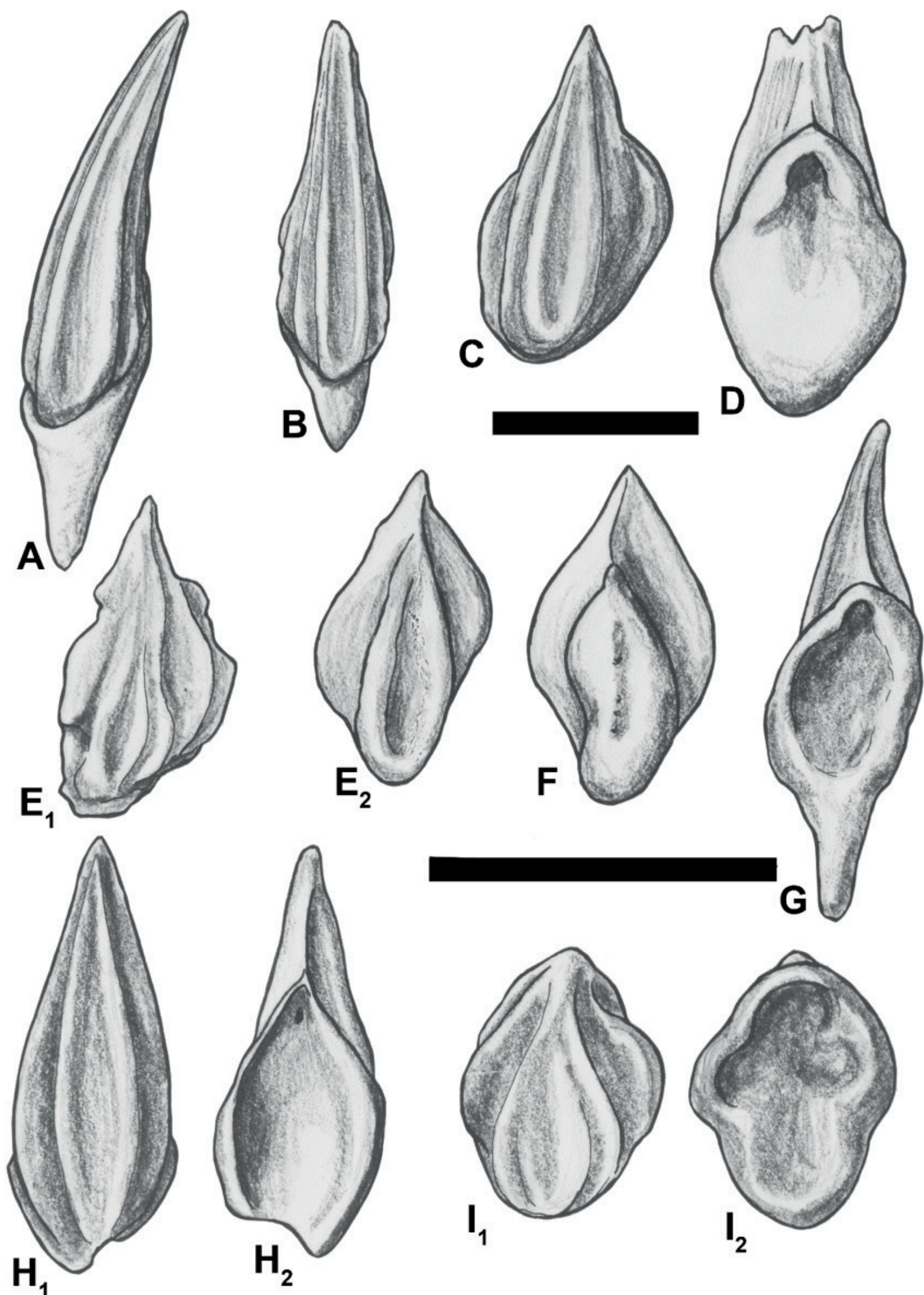

Appendix Figure 1. Drawings of thelodont scales from Susan Turner's PhD-thesis. (A-F) Loganellia cf. aldridgei from Bjellum 1. (G-I) are the L. cf. aldridgei scales of the lost sample PMOGHA2 from the Helgøya Quartzite discussed in the text. Scale bars represent $0.25 \mathrm{~mm}$. 

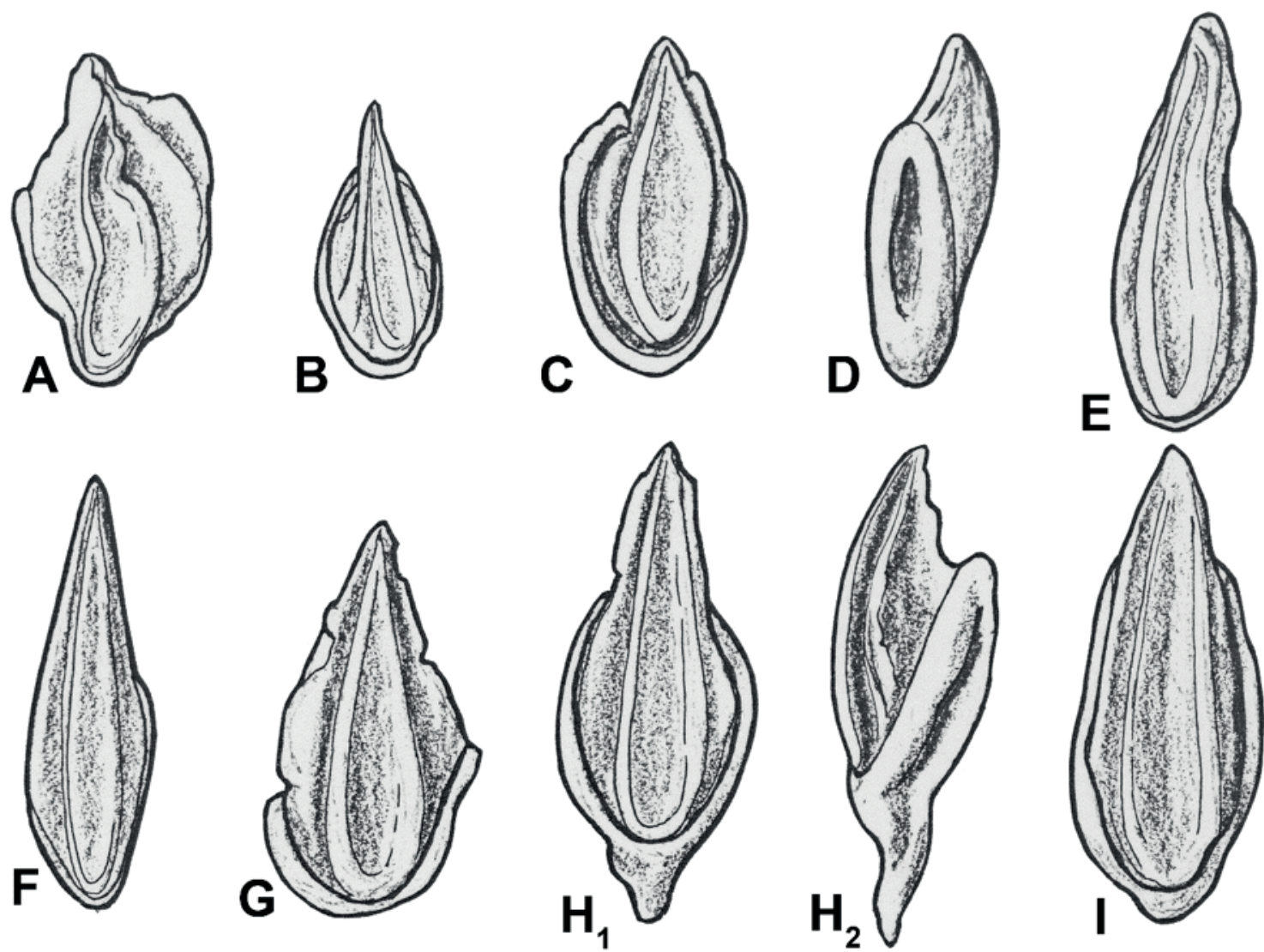

Appendix Figure 2. Drawings of thelodont scales from Susan Turner's PhD-thesis displaying the morphological variation of the scales referred to Loganellia $c f$. aldridgei. 

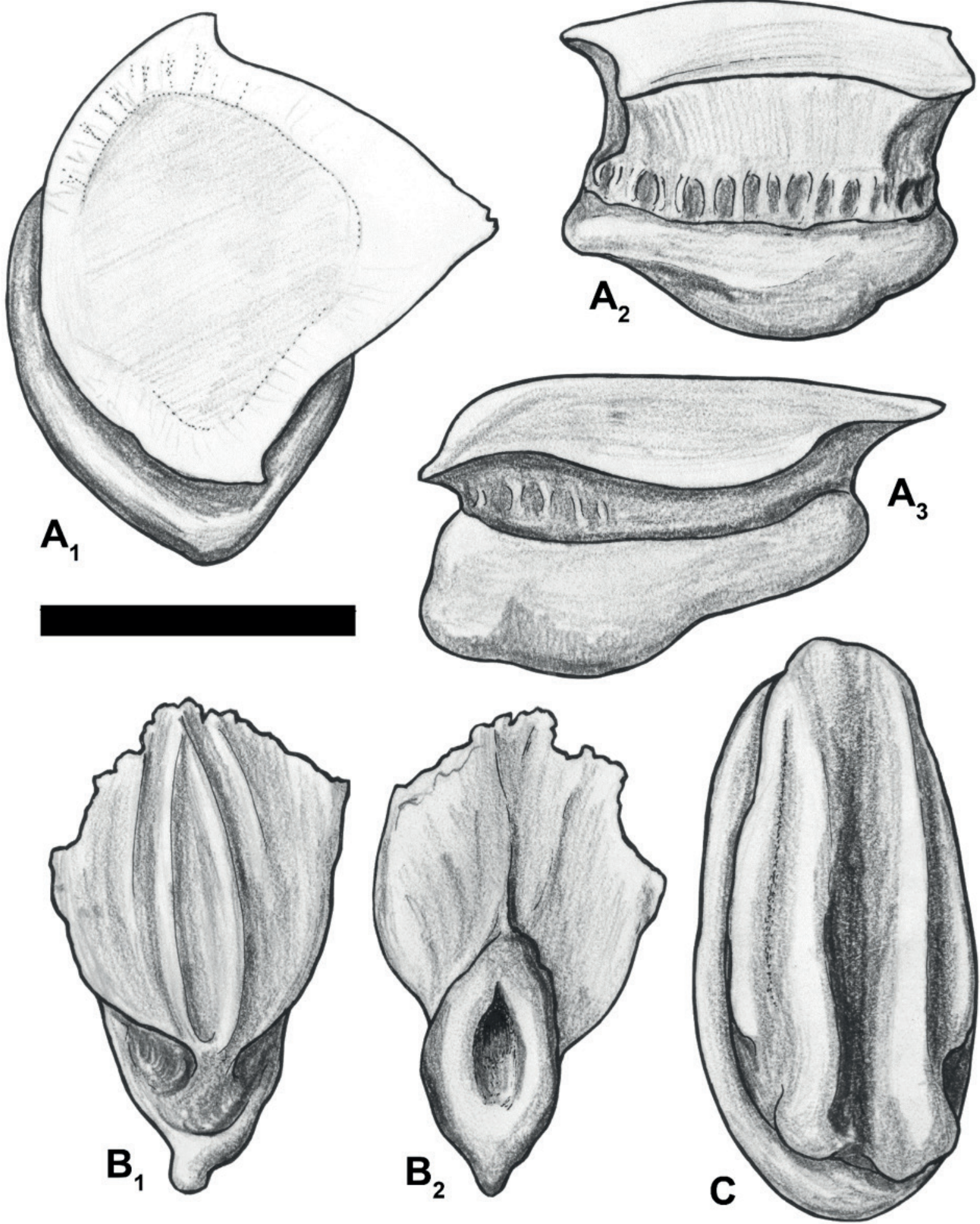

Appendix Figure 3. Drawings of thelodont scales from Sue Turner's PhD-thesis. These are the same as specimens PMO 234.230A-D figured and described in the paper. Scale bar represents $0.5 \mathrm{~mm}$. 

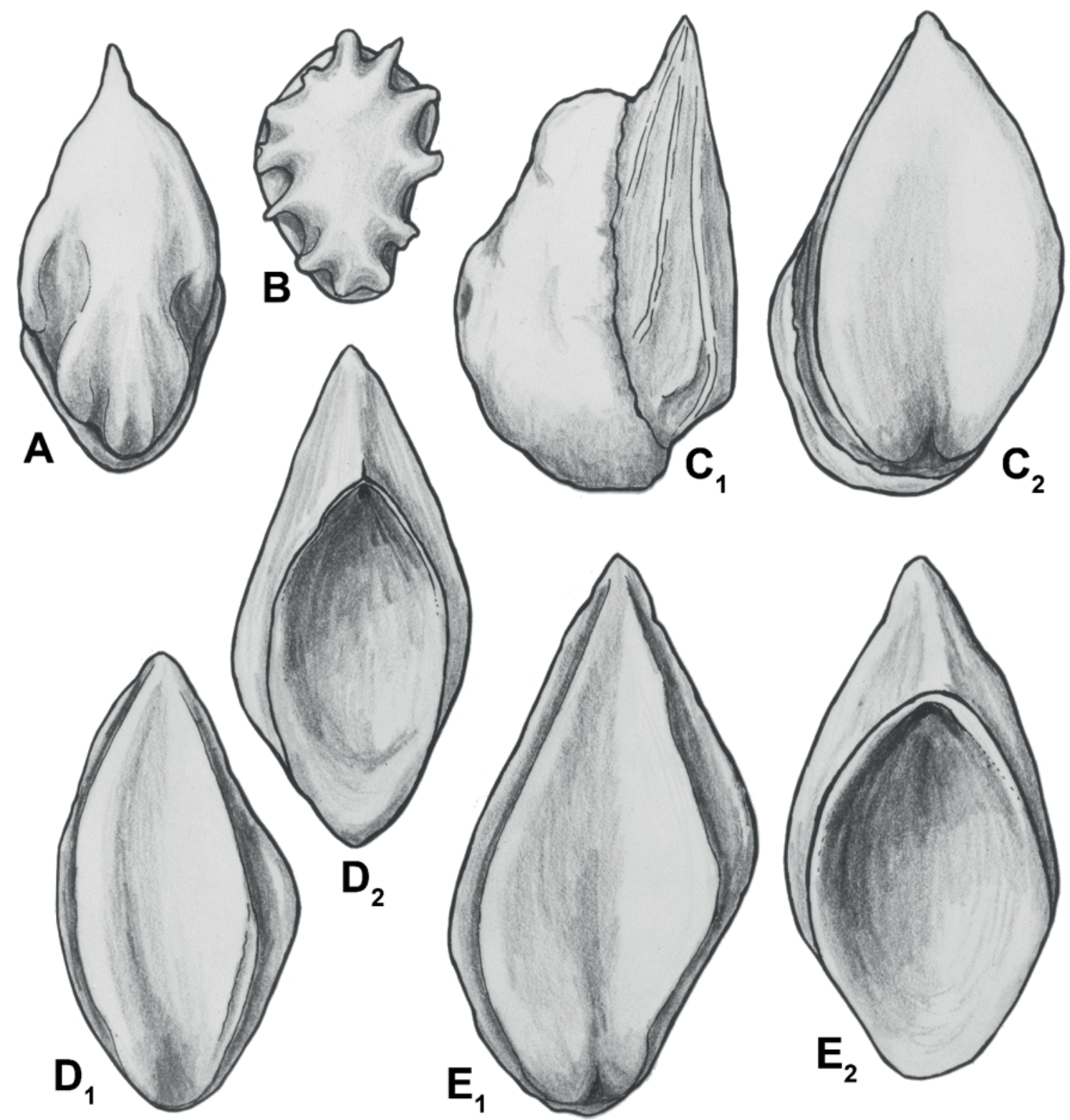

Appendix Figure 4. Drawings of thelodont scales from Sue Turner's PhD-thesis. A-C: Loganellia grossi from Gjettum Station 8. D-E are the only two scales of L. grossi from Gjettum Station 7 (these are the same as specimens PMO 234.231A-B). 


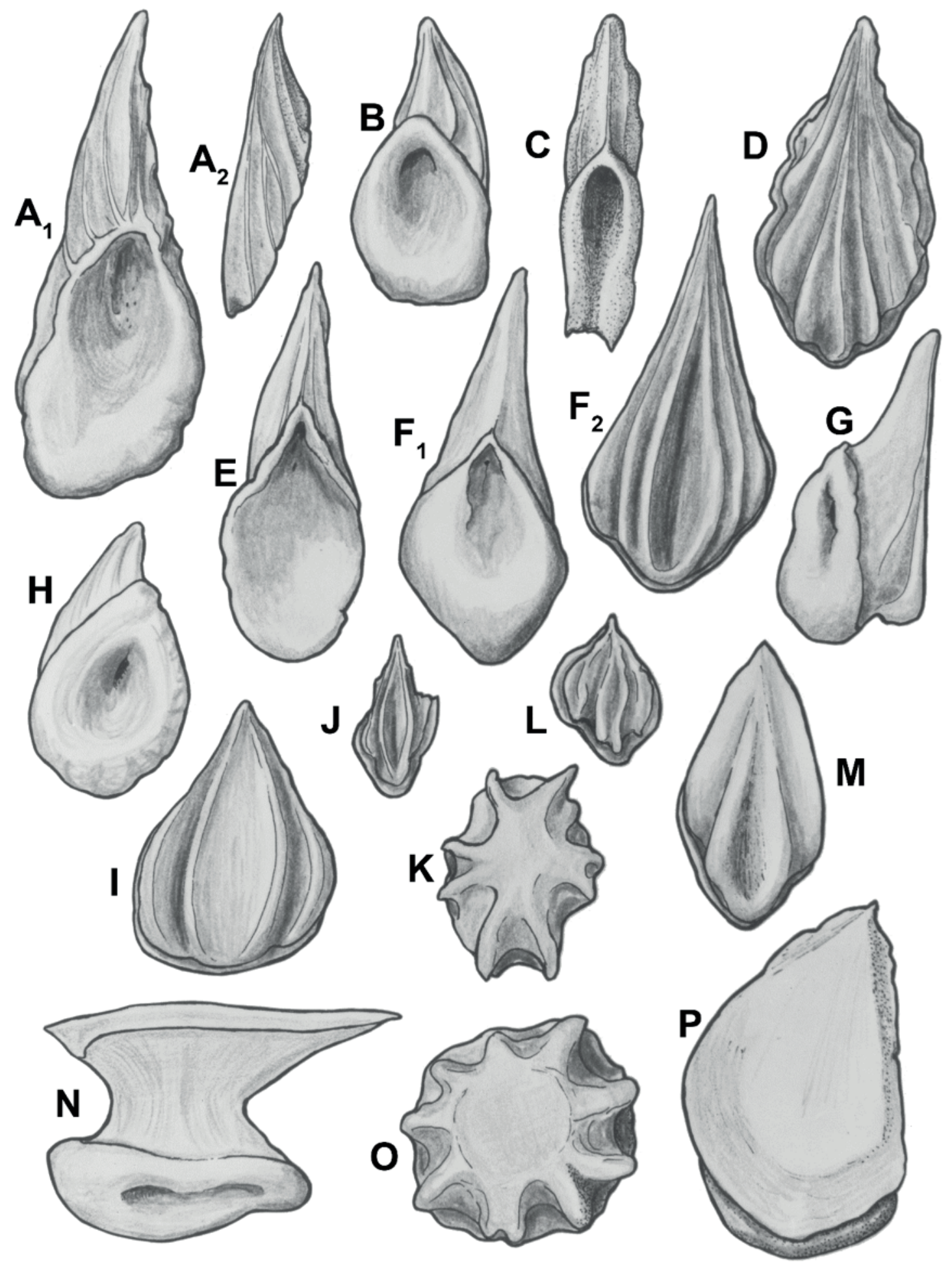

Appendix Figure 5. Drawings of thelodont scales from Sue Turner's PhD-thesis from the Øverland 1 sample. Some of these scales are the same as the ones figured in the paper, for example, $K$ is specimen PMO 234.232G, $O$ is the same as specimen PMO 234.232A, and $M$ is the same as specimen PMO 234.232H. 